DOI: $10.35218 /$ armca.2021.1.06

\title{
Medieval Art, National Architectural Heritage and Museums in Late 19th Century Romania*
}

\author{
Cosmin Minea**
}

\begin{abstract}
This article describes how the material heritage was given new shape and meaning in the context of the new nation-state of Romania. It starts by looking at the history of the first public museum in Romania, namely the Museum of Natural History and Antiquities in Bucharest and also at the broader interest in the Roman antiquities in 19th century Romania. It then focuses on the first restoration of historical monuments and the initiatives of two of the most well-known architects at the time to establish museums of religious art: André Lecomte du Noüy (1844-1914) and Ion Mincu (18521912). The process of creating a national heritage for Romania has led to the design of valuable new buildings and was underpinned by a powerful will to modernise the country. At the same time, it has represented a destructive force. The built fabric of historical sites and historical artefacts were reshaped, rebuilt, given new meanings and context, so that to fit into the political objectives of the new nation-state. The article will balance and analyse the significance of these various efforts to restore historical monuments and establish the first museums of Romanian heritage.
\end{abstract}

Keywords: architectural heritage, historical monuments, modern Romania, Ion Mincu, André Lecomte du Noüy, restoration, modern architecture, heritage preservation, national museums.

\section{Introduction}

The earliest attempts at defining a set of historical monuments as national symbols is closely connected to a growing interest in medieval art and in the cultural identity of modern Romania. The article takes as a starting point the almost unknown attempts to establish museums of religious and medieval art in Romania in order to describe the wider activity of restoring,

\footnotetext{
* This study was supported by the ERC StG-802700 Art Historiographies in Central and Eastern Europe. An Inquiry from the Perspective of Entangled Histories. financed by the European Research Council and hosted by the New Europe College-Institute for Advanced Study, Bucharest. Special thanks for comments and suggestions go to Dr Shona Kallestrup (New Europe College and University of Saint Andrews).

** Cosmin Minea, postdoctoral researcher in the ERC project 'Art Historiographies in Central and Eastern Europe', arthist.ro and future Swiss Excellence Scholar at the ETH, Zürich. Email: cosmin.minea@gmail.com Publications: https://nec-ro.academia.edu/CosminMinea
} 
promoting and defining the historical heritage of the country. It begins with the period of time preceding the creation of modern Romania, by focusing on the vivid interest in local Antiquities, visible in the establishment and running of the Museum of Natural History and Antiquities in the capital Bucharest. It then describes the first missions to document, study and gather medieval artefacts in the country and the first restoration campaign of historical monuments. Part of the activity to reshape and refurbish monuments were also proposals to establish new museums for the religious art, the frescoes and the fragments of architecture from the historical monuments. I use the terms 'medieval' and 'historical', throughout the entire text, as interchangeable concepts, since in the Romanian art historiography terms such as 'medieval' are loosely used to refer to art and architecture from the 13th century up until the late 18th century. In effect, the medieval period is often defined as comprising almost the whole historical time since the first documented political formations on the territory of Romania after the Roman period (12th century-13th century) until the modern state.

The activity of restoring, promoting and displaying religious art is best analysed within the context of a modernising nation-state, in the search for its own cultural identity, but also within the wider European context. Therefore, the article will trace how Western concepts and institutions, such as universal exhibitions, state museums, art galleries or public monuments were interpreted and given new meanings in the Romanian case. It will also bring new information on the history of museum displays in Romania and on some of the best-known architects of the time, namely André Lecomte du Noüy (1844-1914) and Ion Mincu (1852-1912).

The nineteenth century brought sweeping changes in the political status of Wallachia and Moldavia. Firstly, the brief Russian administration of the two provinces (1829-1834) was a period of rapid administrative reform (the first constitution, modern urban plans) and of a first Europeanisation process of the society. Following the Crimean War (1856), Wallachia and Moldavia secured the rights to autonomy and when in 1859 both regions chose the same person as ruler, Prince Alexandru Ioan Cuza (1820-1873), the process of modernisation according to the European model gained full steam. The most visible cultural artefacts and monuments of modern Romania were mostly Orthodox churches and monasteries, together with objects serving their religious practices. The architecture of these monuments was marked by periods of Byzantine, Serbian, Russian, Polish, Hungarian, Ottoman and Oriental influences. As a consequence, there is = difficult to classify them 
according to a fixed artistic pattern, their evolution or defined set of influences. The monastery of Curtea de Argeș (early 16th century), the most well-known monument in the 19th century in Romania, is a case in point. For the sources of its architecture and decoration, scholars have advanced hypothesis ranging from Western and Central Europe to Middle East and Central Asia (Romanesque, Moresque, Venetian, Arab, Persian, Serbian, Armenian or Georgian architecture). ${ }^{1}$ The original and eclectic nature of the monuments was not something to be proud of but an obstacle for 19th century Romanian leaders, who looked to define and promote a clearly recognisable national architectural heritage. As the article will show, the role of museums and of restorations was to a certain extent to order the various objects and monuments according to a clear, rational narrative that had as ultimate purpose to promote a national historical heritage of Romania.

The earliest attempts at defining a set of historical monuments as national symbols is closely connected to a growing interest in medieval art and in the cultural identity of modern Romania. The article takes as a starting point the almost unknown attempts to establish museums of religious and medieval art in Romania in order to describe the wider activity of restoring, promoting and defining the historical heritage of the country. It begins with the period of time preceding the creation of modern Romania, by focusing on the vivid interest in local Antiquities, visible in the establishment and running of the Museum of Natural History and Antiquities in the capital Bucharest. It then describes the first missions to document, study and gather medieval artefacts in the country and the first restoration campaign of historical monuments. Part of the activity to reshape and refurbish monuments were also proposals to establish new museums for the religious art, the frescoes and the fragments of architecture from the historical monuments. I use the terms 'medieval' and 'historical', throughout the entire text, as interchangeable concepts, since in the Romanian art historiography terms such as 'medieval' are loosely used to refer to art and architecture from the

\footnotetext{
${ }^{1}$ Writings about Curtea de Argeș include Ludwig Reissenberger, "Die bischöfliche Klosterkirche bei Kurtea d'Argyisch in der Walachei”, Jahrbuch der Kaiserl. Königl. CentralCommission zur Erforschung und Erhaltung der Baudenkmale, IV (1860).Alexandru TzigaraSmurcaş, Biserica Episcopală din Curtea de Argeş, (Bucharest, 1913); Alexandru Odobescu, Biserica de la Curtea de Argeș, (Bucharest, 1924); Nicolae Ghika-Budești, "Înrâurirea armenească”, Buletinul Comisiunii Monumentelor Istorice, Part. 1, (1927), 140-146, especially 140-143.Gheorghe Balş, Influences arméniennes et géorgiennes sur l'architecture roumaine (Vălenii de Munte, 1931); Emil Lăzărescu, Biserica Mânăstirii Argeşului (The Church of the Argeș Monastery), (Bucharest: Meridiane, 1967). Kirsta Zach, "Der Furstenhof in Argeș”, in Religiöse Erinnerungsorte in Ostmitteleuropa: Konstitution und Konkurrenz, ed. Joachim Bahlcke, Stefan Rohdewald, Thomas Wünsch, (Akademie Verlag, 2013), 99-110. Emanuela Cernea, Oliviu Boldura, et all., Mărturii. Frescele Mănăstirii Argeşului, Exhibition catalogue, (MNAR: Bucharest, 2013).
} 
13th century up until the late 18th century. In effect, the medieval period is often defined as comprising almost the whole historical time since the first documented political formations on the territory of Romania after the Roman period (12th century-13th century) until the modern state.

The activity of restoring, promoting and displaying religious art is best analysed within the context of a modernising nation-state, in the search for its own cultural identity, but also within the wider European context. Therefore, the article will trace how Western concepts and institutions, such as universal exhibitions, state museums, art galleries or public monuments were interpreted and given new meanings in the Romanian case. It will also bring new information on the history of museum displays in Romania and on some of the best-known architects of the time, namely André Lecomte du Noüy (1844-1914) and Ion Mincu (1852-1912).

The nineteenth century brought sweeping changes in the political status of Wallachia and Moldavia. Firstly, the brief Russian administration of the two provinces (1829-1834) was a period of rapid administrative reform (the first constitution, modern urban plans) and of a first Europeanisation process of the society. Following the Crimean War (1856), Wallachia and Moldavia secured the rights to autonomy and when in 1859 both regions chose the same person as ruler, Prince Alexandru Ioan Cuza (1820-1873), the process of modernisation according to the European model gained full steam. The most visible cultural artefacts and monuments of modern Romania were mostly Orthodox churches and monasteries, together with objects serving their religious practices. The architecture of these monuments was marked by periods of Byzantine, Serbian, Russian, Polish, Hungarian, Ottoman and Oriental influences. As a consequence, there is = difficult to classify them according to a fixed artistic pattern, their evolution or defined set of influences. The monastery of Curtea de Argeș (early 16th century), the most well-known monument in the 19th century in Romania, is a case in point. For the sources of its architecture and decoration, scholars have advanced hypothesis ranging from Western and Central Europe to Middle East and Central Asia (Romanesque, Moresque, Venetian, Arab, Persian, Serbian, Armenian or Georgian architecture). ${ }^{2}$ The original and eclectic nature of the

\footnotetext{
${ }^{2}$ Writings about Curtea de Argeș include Ludwig Reissenberger, "Die bischöfliche Klosterkirche bei Kurtea d'Argyisch in der Walachei", Jahrbuch der Kaiserl. Königl. CentralCommission zur Erforschung und Erhaltung der Baudenkmale, IV (1860).Alexandru TzigaraSmurcaş, Biserica Episcopală din Curtea de Argeş, (Bucharest, 1913); Alexandru Odobescu, Biserica de la Curtea de Argeș, (Bucharest, 1924); Nicolae Ghika-Budești, "Înrâurirea armenească”, Buletinul Comisiunii Monumentelor Istorice, Part. 1, (1927), 140-146, especially 140-143. Gheorghe Balş, Influences arméniennes et géorgiennes sur l'architecture roumaine (Vălenii de Munte, 1931); Emil Lăzărescu, Biserica Mânăstirii Argeşului (The Church of the Argeș Monastery), (Bucharest: Meridiane, 1967). Kirsta Zach, "Der Furstenhof in Argeș”, in Religiöse Erinnerungsorte in Ostmitteleuropa: Konstitution und Konkurrenz, ed. Joachim Bahlcke, Stefan Rohdewald, Thomas Wünsch, (Akademie Verlag, 2013), 99-110. Emanuela
} 
monuments was not something to be proud of but an obstacle for 19th century Romanian leaders, who looked to define and promote a clearly recognisable national architectural heritage. As the article will show, the role of museums and of restorations was to a certain extent to order the various objects and monuments according to a clear, rational narrative that had as ultimate purpose to promote a national historical heritage of Romania.

\section{The Museum of Antiquities in Bucharest and the first attempts to display 'national' Romanian art}

Romania's first decades of independence were marked by the actions of a Western-educated, liberal elite that oversaw a process of modernisation, based on emulating Western nation-states. Part of the process was the constitution, promotion and display of a set of buildings and artefacts representative for the culture and history of Romania. Throughout the period, the leading Romanian intellectuals interested in the material heritage were primarily concerned with the remains of Antiquity. In the case of Romania, the antiquities also carried significant national symbolism. They were classified as 'Roman art' and were perceived as material proofs of the Latin origins of the Romanians, the so-believed quintessential national characteristic. Activities of uncovering, documenting and researching the ruins of Antiquity were carried on a regular basis, as seen, for example, in the publications of Alexandru Odobescu or Grigore Tocilescu. ${ }^{3}$

The first public museum in Romania, the Museum of Natural History and Antiquities (founded in 1834 and hosted within the 'Saint Sava' College, the most advanced educational institution in the country), was the centre of the efforts to collect and display Roman Antiquities. Initially, it was very similar with the private curiosity collections of aristocrats, well-known at the time. In fact, the initial collection of the museum comprised the personal curiosity collection of the boyar Mihalache Ghica (1792-1850), that included a range of natural history objects, antiquities, a numismatic collection, copies of Roman sculptures, etc. In 1850, a picture gallery was included in one of the rooms of the museum with the works of the most significant contemporary painters (such as Gheorghe Tattarescu and Constantin

Cernea, Oliviu Boldura, et all., Mărturii. Frescele Mănăstirii Argeşului, Exhibition catalogue, (MNAR: Bucharest, 2013).

${ }^{3}$ Alexandru Odobescu, Rămășițe antice din Județul Dorohoiu (1872), Antichitățile județului Romanați(1877), both published in Alexandru Odobescu, Opere complete, vol. 3, (Bucharest, 1906). Grigore Tocilescu, Documente privitoarere la Istoria Romanilor, (Bucharest, 18851886). Grigore Tocilescu, Otto Benndorf and George Niemann, Das monvment von Adamklissi, Tropaevm Traiani, (Vienna, 1895). 
Lecca). ${ }^{4}$ A new museum was opened as Museum of Antiquities in the new university building in Bucharest, in 1865, that published its inventory for the first time and acquired objects according to a new law, Regulation for exploitation and acquisition of antique objects (1874). In 1875, four new sections of the museum were established, which indicated a clear will to gather and display a diverse national cultural heritage: the section of 'national costumes', meaning folk clothing; the section of paintings having as central theme the national history and heritage; the section of precious stones, and an industrial section showcasing the modernisation of Romania. From 1881 to 1909 the director of the museum was Grigore Tocilescu, the main archeologist of Romania, who would continue to enrich the collection of the museum.

The attention on antiquities is further proven by other much smaller regional museums that started to emerge at the end of the 19th century, such as the history and archeological collection in Târgu-Jiu, predecessor of the Gorj Museum (founded in 1893) and the Câmpulung Museum (founded in 1889) within Negru Vodă Monastery. ${ }^{5}$ They all focused their collection on archeology, coins or natural history, directly copying the former cabinets of curiosities of the early-modern period. ${ }^{6}$

In spite of the great symbolic significance given to Antiquity, most of the material heritage and the known history of Wallachia and Moldavia were the product of the period starting from the 14th century. If Antiquity was more important because it was considered the alleged moment of birth of the Romanian 'nation', the medieval period and consequently its historical monuments constituted in the eyes of local intellectuals the proof of Romanian continuity on the present lands, from Antiquity until contemporary times. Since religious art comprised most of the surviving material heritage of the past (surviving examples of princely, courtly or military art were scarce), the significance given to it was substantial.

The importance of religious monuments is confirmed by the fact that in the very first year after Romania was formed, in 1860, the state organised a set of study trips throughout the country in order to document artistic and historical artefacts. Its scope was to gather and study artefacts from the historical monasteries in Romania. Notably, the trips focused on movable objects and not on architecture or decoration of monuments, having as

\footnotetext{
${ }^{4}$ Mirela Târnă, "Conceptul de Muzeu National - Studiu De Caz: Muzeul NationaL De Antichităti Din Bucuresti”, Bucureşti. Materiale de istorie şi muzeografie, Vol. XIX, (2005), 360-372, 364.

${ }^{5}$ Details in Vasilica Asandei, Arheologie Și Muzeologie în România la Sfârșitul Secolului Al Xix-Lea Și Inceputul Secolului Al Xx-Lea (Metode Și Concepții), PhD Thesis, Universitatea „Alexandru Ioan Cuza” Din Iaşi, Facultatea De Istorie, (2020).

${ }^{6}$ Vasilica Asandei, Arheologie Și Muzeologie în România la Sfârșitul Secolului Al Xix-Lea Și Inceputul Secolului Al Xx-Lea (Metode Și Concepții), PhD Thesis, Universitatea „Alexandru Ioan Cuza" Din Iaşi Facultatea De Istorie, (2020), 14.
} 
declared focus to gather 'the archeological, archival and bibliographic treasures' of the country. ${ }^{7}$ Therefore, four teams were assigned to explore different parts of the country, each formed by a historian and an artist that would draw copies after the objects found. In the end, there were involved in the trips' activities six people, out of which two painters: Henri Trenk (18181892) and Gheorghe Tattarescu (1820-1894). ${ }^{8}$ The 1860 trips produced reports to the ministry, some published lists and descriptions of monuments and objects and newly acquired pieces for the Museum of Antiquities. ${ }^{9}$ Other trips to document the religious monuments in Romania, equally marked by an interest in the mobile artefacts and in the written inscriptions, followed in 1871,1882 and $1887 .{ }^{10}$

Artefacts were seen as more significant for the Romanian state, because of the already established tradition of antiquarian collections, but also owing to the fact that they could be displayed at the first public museum in the country, the Museum of Natural History and Antiquities and thus could become part of an emerging national heritage. For example, Odobescu published only objects and inscriptions, while ignoring the architecture and decoration of Curtea de Argeș monastery. ${ }^{11}$ On the other hand, Henri Trenk's romantic watercolours taken during the documentary trip also reveal that the monuments were not given much significance. In his view of Curtea de Argeș for example, one cannot distinguish the architectural features of the church, and the focus is placed on the general picturesque landscape (Figure1).

\footnotetext{
${ }^{7}$ Aurelian Sarcedotianu, Cercetări istorice și pitorești prin mânăstirile noastre acum optzeci de ani, [Picturesque and historical research in our monasteries eighty years ago] (Bucharest, 1941), 2. More details about the trips in Alexandru Istrate, De la gustul pentru trecut la cercetarea istoriei. Vestigii, călătorii și colecționari în România celei de-a doua jumătăți a secolului XIX, (Iași: Editura Universităţii Al. I. Cuza din Iaşi, 2015); Ada Hajdu, "În Căutarea Patrimoniului. Excursiile Patriotice Și Arhitectura Națională Românească În Secolul al XIXLea," in Călători Și Călătorii. A Privi, a Descoperi, ed. Bogdan Cristina and Marin Barutcieff Silvia, vol. 1 (Bucharest: Editura Universităţii din București, 2016), 149-68.

${ }^{8}$ The historians were mostly specialists in Roman antiquities (Alexandru Odobescu, Cezar Bolliac, Alexandru Pelimon, Dumitru Pappazoglu).

${ }^{9}$ Alexandru Pelimon, Descrierea Sfintelor Monastiri, de A. Palemon. Memoriu. (Bucharest, 1861); Cesar Bolliac, Monastirile din Romania. (Monastirile inchinate), (Bucharest, 1862). Ada Hajdu, "În Căutarea", 11.

${ }^{10}$ Alexandru Odobescu, "Chestionarul Odobescu", 1871-1874, Manuscript 223-230, Library of the Romanian Academy, Manuscript Cabinet. Pantazi Ghika, Monumente Naționali. Monastiri și biserici ortodocse. Raporturi de la comisiunile intocmite pentru cercetarea lor, Vol 1, (Bucharest, 1882); Ioan Slavici, George Mandrea, Monumente Naționali. Monastiri și biserici ortodocse. Raporturi de la comisiunile întocmite pentru cercetarea lor, Vol 2, (Bucharest, 1882); Grigore Tocilescu, Raporturi asupra câtorva mănăstiri, schituri și biserici din țeră, (Bucharest, 1887). See also a recent study of these documentary trips in Ada Hajdu, "În Căutarea..."

${ }^{11}$ Report from August 17, 1860 in Sarcedoteanu, Cercetări istorice, 16.
} 


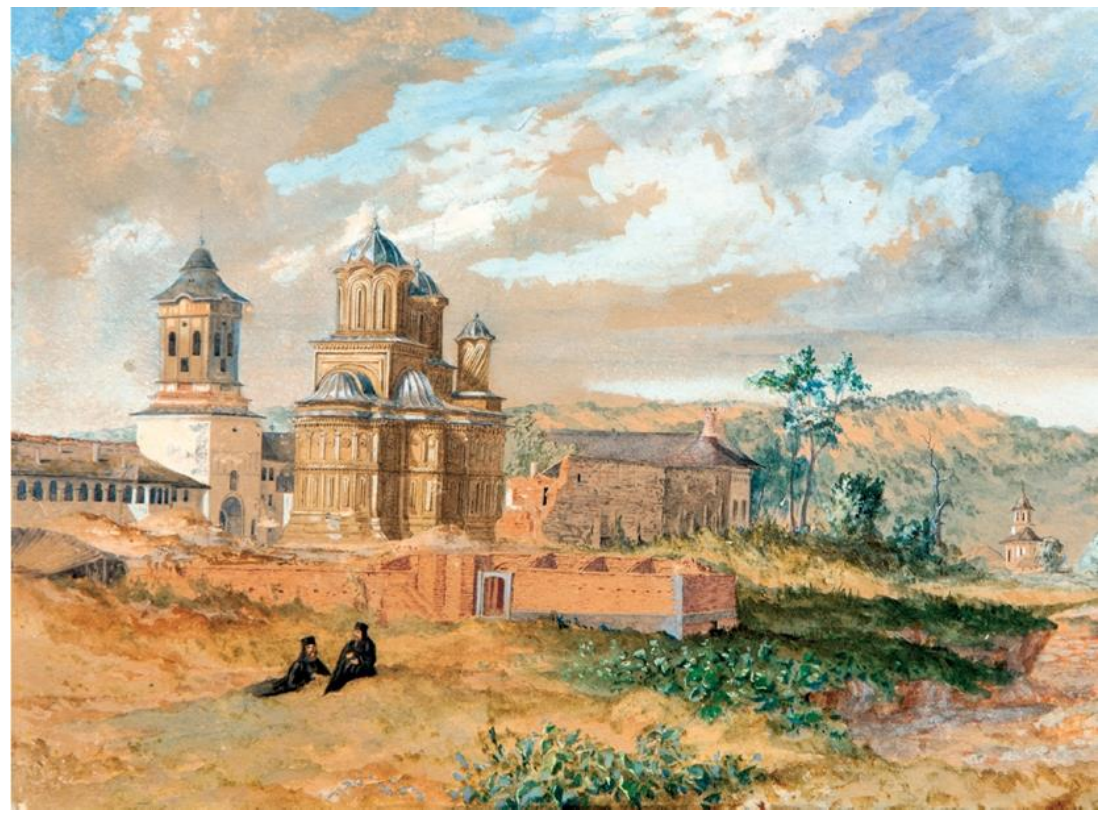

Figure 1: Henri Trenk, View of Curtea de Argeș, Watercolour, 1860.

Romania had to organise a national exhibition of its most significant pieces of cultural heritage when it participated at the Universal Exhibition of 1867 in Paris. Its organiser, Alexandru Odobescu, hoped that Romanian art 'will cause a sensation in the artistic world, especially today, when the civilized Europe is tired of overused styles and eagerly looks towards Byzantine architecture for decorative motifs'. ${ }^{12}$ He indeed focused on unusual cultural products, that he hoped to raise the interest of the French audience, such as religious artefacts, folk costumes, sculptures, a reproduction of Curtea de Argeș church, pictures with monuments ${ }^{13}$ and others (Figure 2). The Romanian pavilion, loosely inspired by Curtea de Argeș church and Stavropoloes Monastery, was also promoted by Odobescu as an original object of study: 'This style has a very particular aspect, that could provide an interesting field of archeological studies, in spite of some analogies with religious constructions in Russia and some details of Arab origins. ${ }^{14}$

\footnotetext{
${ }_{12}$ Alexandru Odobescu, Scrieri Literare si Istorice, (Bucharest, 1887), 86.

${ }^{13}$ See Alexandru Odobescu, Petre Aurelian, Notice sur la Roumanie: principalement au point de vue de son économie rurale, industrielle et commerciale, (Paris: A. Franck, 1868); Alexandru Odobescu, Notice sur les antiquites de la Roumanie, (Paris: A. Franck, 1868).

${ }^{14}$ Odobescu, Aurelian, Notice sur la Roumanie, 317. See also Cosmin Minea, "The Monastery of Curtea de Argeș and Romanian Architectural Heritage in the Late 19th Century," Studies in History and Theory of Architecture 4 (2016): 191-94.
} 
However, French commentators saw the same 'Romanian' architecture differently, as indicating an oriental culture, heavily decorated and with bright colours; they were confused by the Orthodox religion for a Latin nation. ${ }^{15}$ One author wondered: 'Romania does not exist by itself. It does not shine. (...) It is Greek, Russian, French, German, what else?'. ${ }^{16}$ Another commentators found the architecture comparable with that of a mosque, concluding that it is an art in-between, that searches for its character but does not find it, in the same way as the country that represents it. $^{17}$
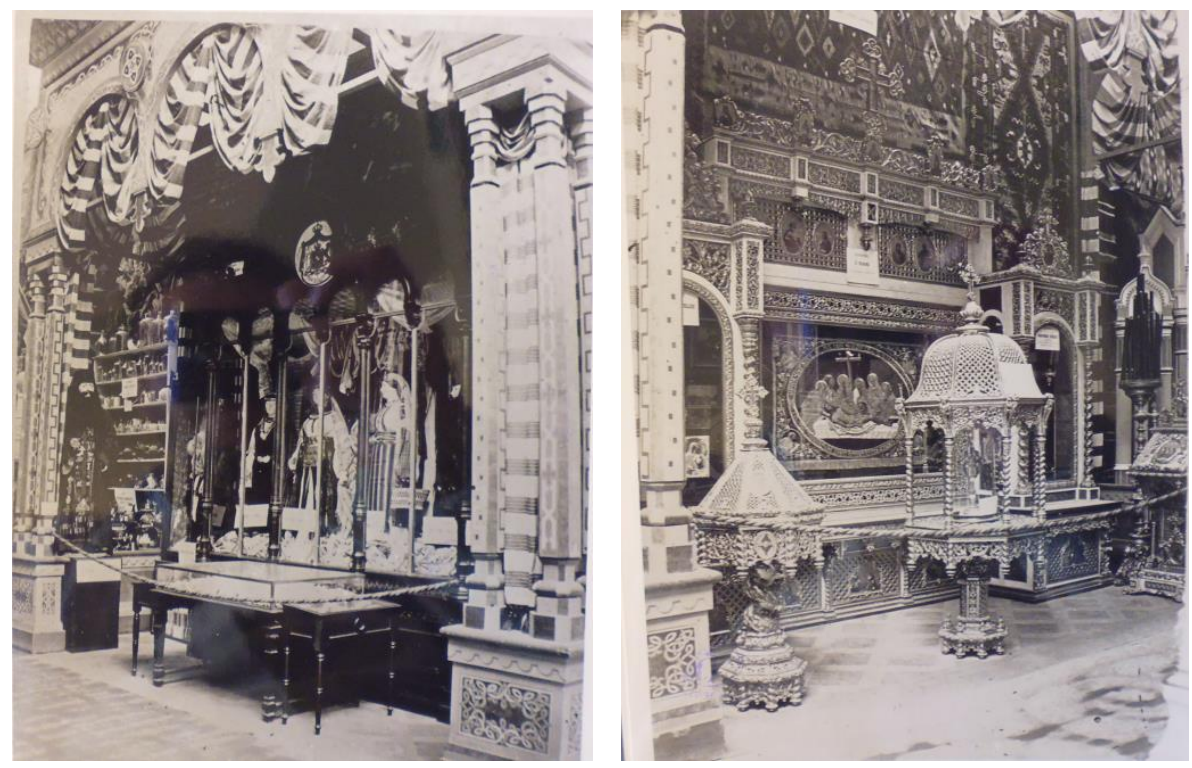

Figure 2: Bisson Freres Studio, view of the Romanian section, 1867 Paris Universal Exhibition

Indeed, Odobescu's efforts to present Romania as an original and innovative nation backfired and ended up by indicating precisely what Romanian intellectuals desired less, namely that Romanian art and culture was similar to that of regions and outside the canon of European art. This lack of identity in the European context, the 'in-betweenness' of Romanian culture, that lies outside recognised categories, is not a problem specific to the 19th century alone. Recent appeals at a more 'horizontal', inclusive art history are proof of the present attempts to overcome divisions based on

\footnotetext{
${ }^{15}$ Laurențiu Vlad, Imagini ale identităţii naţionale. România şi expoziţiile universale de la Paris, 1867-1937, (Iași: Institutul European, 2007, 84 - 85).

${ }^{16} L^{\prime}$ Exposition illustrée, tom II, 1900, 130-132.

${ }^{17}$ François Ducuing, "L'Eglise roumaine”, in L'Exposition illustrée, tom I, (1867), 53.
} 
notions of centres and peripheries in Central and Eastern Europe. ${ }^{18}$ In the 19th century, this image of Romanian culture as rather exotic and outside the European canon, fuelled a constant need for affirmation and redefinition that led to the first attempts to establish museums of religious art in the country and to the restoration of monuments.

\section{The restoration of Trei Ierarhi Monastery and the proposed first public museum of Iași}

One of the most visible attempts to promote a national cultural identity for Romania was the long and extensive campaign to restore the most significant architectural monuments in the country, led from 1875 to 1904 by the French architect André Lecomte du Noüy (1844-1914). The way monuments were transformed reveals the vivid desire of both domestic and foreign actors to refashion the past material heritage of Romania in order to integrate it into the European culture. In the second half of the nineteenth century, in most regions of Europe the symbolical significance of historical monuments grew exponentially. If just a few decades before they were opportunities for remembering a lost past or for romantic daydreamers, historical monuments quickly came to embody the present and future aspirations of nation-states and empires. ${ }^{19}$ Old ruins were restored into shiny new cathedrals or castles (notably in France, restored by Eugène Viollet-leDuc; or Friedrich Schmidt in Austria), old unfinished constructions were completed (such as Cologne Cathedral) or some other monuments were refurbished in order to represent in a more fitting way the national history and culture of 'the people'. Romania was not an exception. Architects and intellectuals gave new meanings and transformed monuments through writings and restorations, that translated into very visible modifications to the fabric of buildings and their surroundings.

\footnotetext{
${ }^{18}$ See recently, including a review of some major attempts to Petra Brouwer \& Kristina Jõekalda, "Introduction: architectural identities of European peripheries", (2020), The Journal of Architecture, 25:8, 963-977. Also, Carmen Popescu, "Cultures majeures, cultures mineures'. Quelques réflexions sur la (géo)politisation du folklore dans l'entre-deux-guerres", in Spicilegium. Studii și articole în onoarea Prof. Corina Popa, (Bucharest: UNArte, 2015); Piotr Piotrowski, "Toward a Horizontal History of the European Avant-Garde," in Europa! Europa? The Avant-Garde, Modernism and the Fate of a Continent, ed. Bru Sascha (De Gruyter, 2009), 49-58. Foteini Vlachou, "Notes from the Periphery: History and Methods", Visual Resources, Volume 35, Issue 3-4, 2019, 193-199.

${ }^{19}$ See Jukka Jokilehto, A History of Architectural Conservation (Oxford: ButterworthHeinemann, 2002), 137-73.Miles Glendinning, The Conservation Movement: A History of Architectural Preservation: Antiquity to Modernity (New York: Routledge, 2013). Brenda Schildgen, Heritage or Heresy: Preservation and Destruction of Religious Art and Architecture in Europe (New York: Palgrave Macmillan, 2016).
} 


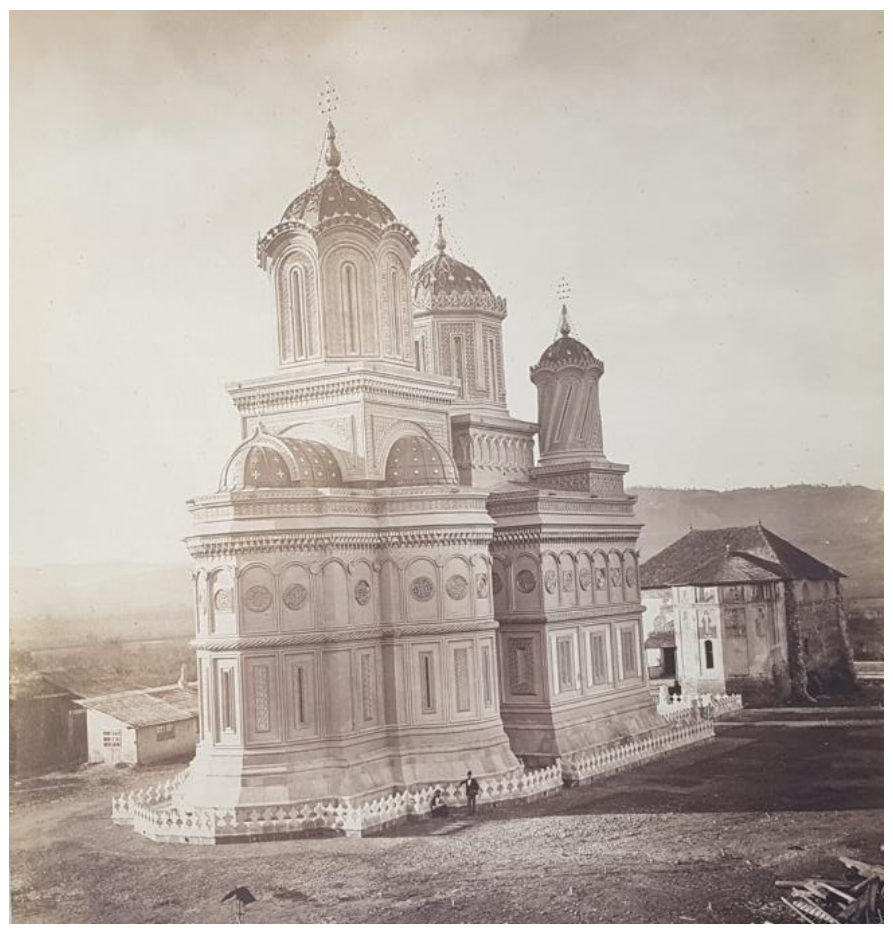

Figure 3: Curtea de Argeș after the exterior restoration (around 1881).

Lecomte du Noüy oversaw the restoration of the former monastery of Curtea de Argeș (between 1875-1886), the church of Trei Ierarhi (18811890), the Princely Church Saint Nicholas in Iași (1886-1904), the Metropolitan Church in Târgoviște (1885-1895), and Saint Dimitry Church in Craiova (1887-1896). He was recommended by Viollet-le-Duc, the leading French restorer of the time, who previously studied the restoration of Curtea de Arges at the request of the Romanian authorities. ${ }^{20}$ The fact that politicians such as Titu Maiorescu (1840-1917), then the Minister of Religious Cults and Public Education, or the historian Alexandru Odobescu, asked Viollet-le-Duc to study the restoration of a Romanian monument, is a testament for their confidence in but also within the French cultural milieu, where they were also educated.

At Curtea de Arges, Lecomte du Noüy reconstructed identically the main tower, many of the decorations and only changed minor details, such as the wreaths to the domes. However, he completely remade the interior of the church with brand new neo-Byzantine frescoes, demolished its surrounding

\footnotetext{
20 "Letter to the Minister of Religious Cults and Pulic Instructions", August 20, 1874, leaf 173, dossier no. 127, year 1874, Fonds Ministry of Religion and Public Instructions, National Archives of Romania, Bucharest.
} 
buildings and built instead an Episcopal Palace. ${ }^{21}$ His restoration singled-out the monument, placing it in a vast open landscape, extracted from its historical context, in the manner of museum displays (Figure 3).

His second restoration, began in 1882 , was that of the 17 th century Trei Ierarhi monastery (built between 1637 and 1639) in Iași, long regarded as the most beautiful in Romania, a Moldavian equivalent of Curtea de Argeș, and also a symbol for the cultural and religious patronage of the Moldavian Voivode Vasile Lupu (who reigned between 1634-1653). ${ }^{22}$ The monastery comprised lodgings for monks, a refectory, a bell-tower, a religious school for the study of Latin and Slavonic languages (Academia Vasiliană), a printing press and the princely residence. It also hosted the remains of Saint Paraskeva (venerated throughout the Balkans). Architecturally, the church stands out through its exterior decorations, in particular its uniquely rich and fastidious stone carvings from top to bottom, interrupted only by a central stone belt, specific to Wallachian churches (Figure 4). The decoration is somehow similar to some early medieval Russian churches, such as the one in Vladimir (Figure 5); indeed, most likely the architect and stonemasons were trained and based in the Russian Empire. If its decoration is unique for at least Central and Eastern Europe, structurally, the church is similar to other Moldavian monuments with an elongated trefoil plan, the specific diagonal 'Moldavian' vaults and Gothic door and window frames. ${ }^{23}$

\footnotetext{
${ }^{21}$ Carmen Popescu, “André Lecomte Du Nouÿ (1844-1914) et La Restauration Des Monuments Historiques En Roumanie," Bulletin de La Société de l'Histoire de l'Art Français. Année 1998, 1999, 287-308.

${ }^{22}$ See an official description in "Report", October 20, 1881, Restaurarea monumentelor istorice, 1865-1890, Acte şi rapoarte oficiale, ( Bucharest , 1890), 121-122: "It is indeed at the same level with Curtea de Argeș". Also see the opinion of the contemporary art history teacher Nicolae Idieru: Nicolae Idieru, Istoria Artelor Frumoase, (Bucharest, 1898), 116: "Trei Ierarhi is almost as accomplished as Curtea de Argeș". See more details about Trei Ierarhi in English in Alice Isabella Sullivan, "Ecclesiastical Art and Architecture at the Crossroads: The Three Hierarchs Church in Iaşi" in George Lăzăroiu, ed., Thraco-Dacian and Byzantine Romanity of Eastern Europe and Asia Minor, vol. XI, (New York: The Romanian Institute of Orthodox Theology and Spirituality, 2012). In Romanian, see Dan Bădărău and Ioan Caproșu, Iaşii Vechilor Zidiri: Pînă La 1821 (Iași: Demiurg, 2007), 182-84; Ana Dobjanschi, Victor Simion, 'Un climat nou de arta in epoca lui Vaslie Lupu', Revista Muzeelor si Monumentelor, XV, (1984).

${ }^{23}$ Its prototype in terms of structure, plan and elevation is Galata Monastery, also in Iaşi (built between 1582-1584), while some of the decorations are similar to those of Dragomirna Monastery (built between 1602-1609), near Suceava, $140 \mathrm{~km}$ away.
} 

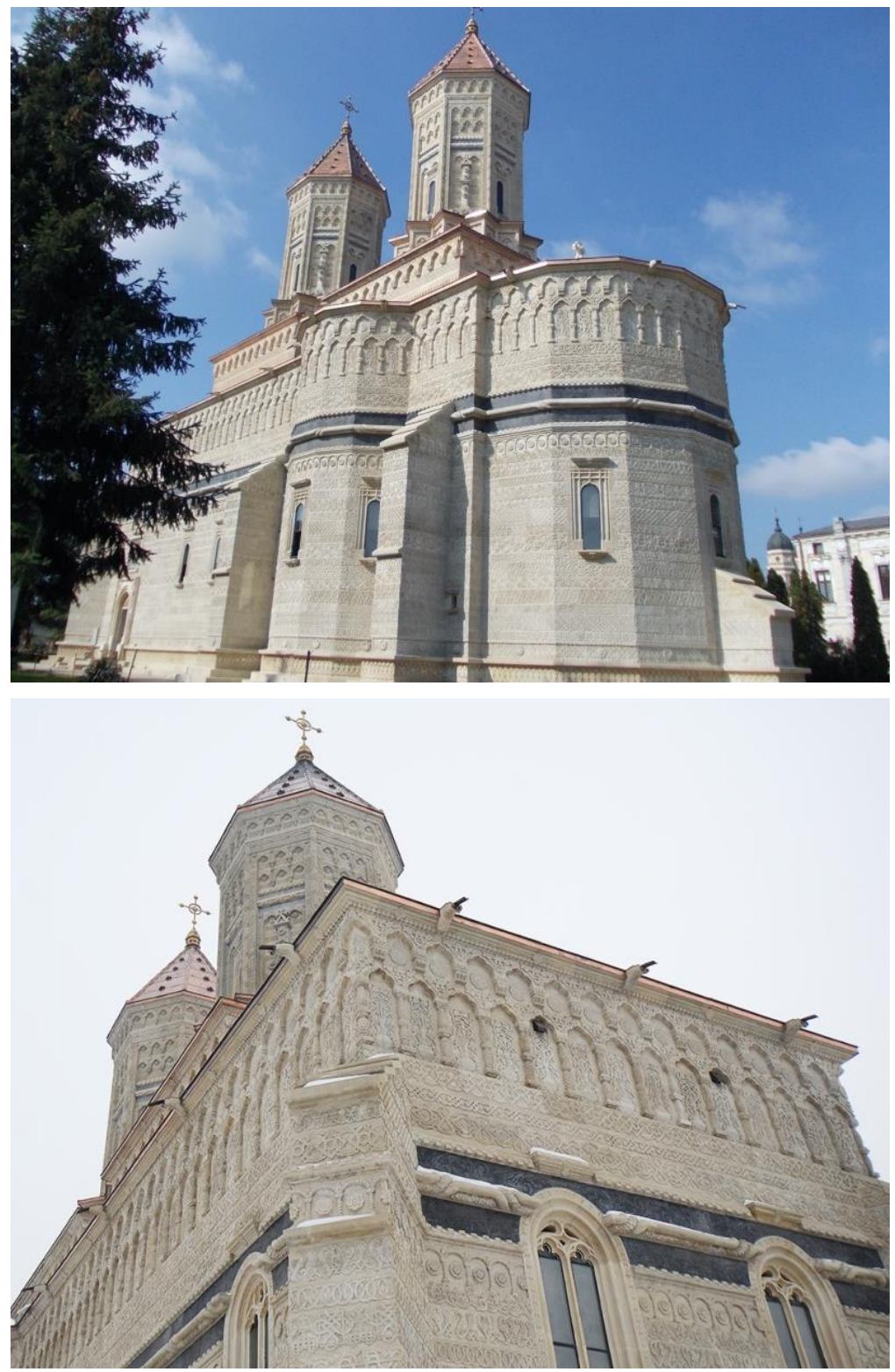

Figure 4: Trei Ierarhi Church, Iași, seventeenth century, restored between 1884-1887. 


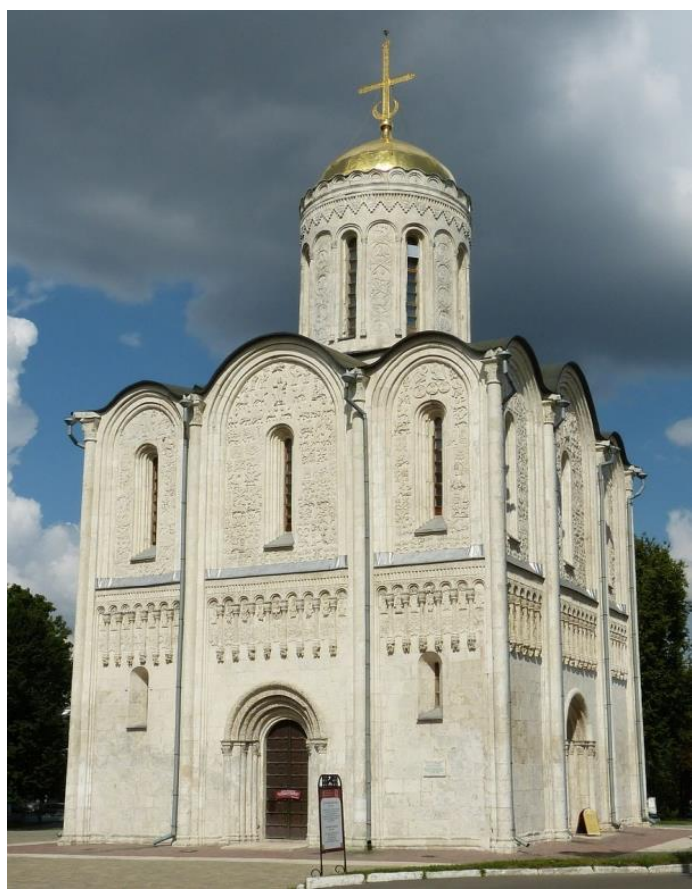

Figure 5: Cathedral of Saint Demetrius, Vladimir, Russia (late twelve century) displaying the same rich stone-carved decoration on the exterior façade as Curtea de Argeș and Trei Ierarhi churches and which Viollet-le-Duc compared with previous Armenian and Georgian monuments.

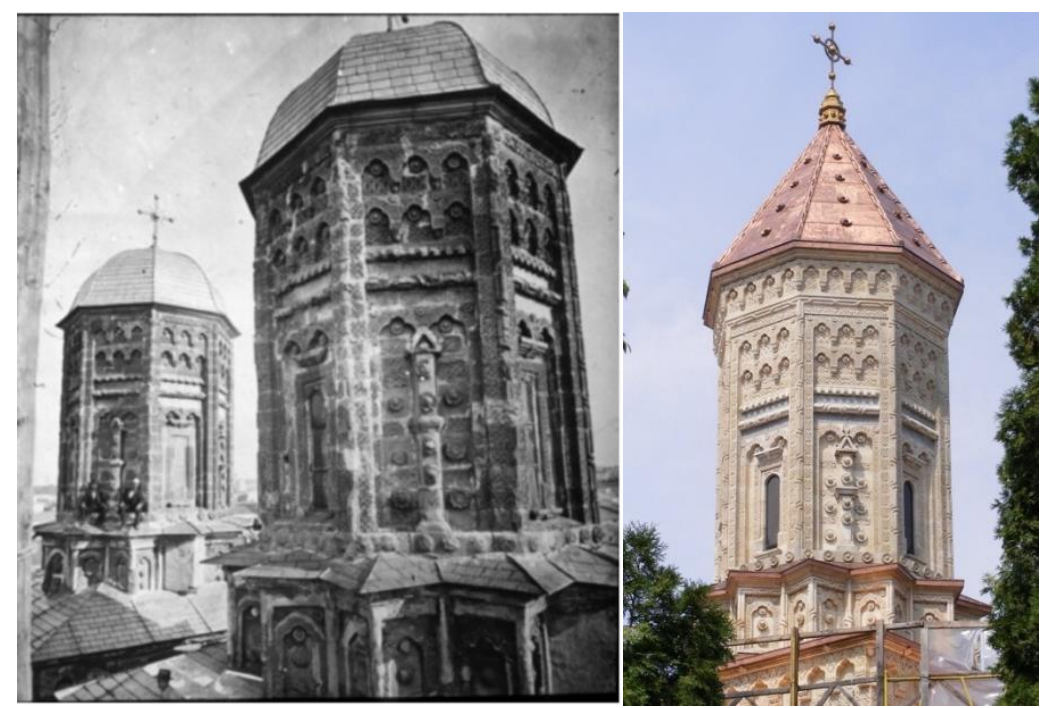

Figure 6: Comparison between the roof and towers before and after the restoration. 
The Government was keen to vastly transform the monument and the surroundings, as in the case of Curtea de Argeș. For that reason it proposed a program that included, besides the restoration of the church and the tower of the monastery, the demolition of nearby constructions and the building of a statue of Vasile Lupu, the founder of the monastery. ${ }^{24}$ As a response, Lecomte du Noüy came with an even bolder proposal, namely to demolish and reconstruct the entire monument. ${ }^{25}$ In the end, he only reconstructed the upper part, including the cornice, the roof and the two towers, representing half of the exterior surface of the monument. ${ }^{26}$ His reconstructions were not simply copies of the former architecture, but creative interpretations as indicated by the addition of an extra row of round arches at the towers and the changed shape of the roof. (Figure 6) The restoration of the interior (approx. 1887-1890) brought, as in the case of Curtea de Argeș, entirely new frescoes and furniture.

The immediate surroundings of the monastery raised special problems. Contrary to the former monastery of Curtea de Argeș, Trei Ierarhi had not been an isolated monastery, near a village. On the contrary, it was built in the middle of a thriving city, at the time the second biggest in Romania after Bucharest. It was on the main thoroughfare, surrounded closely by merchant houses, inns and dwellings (Figure 7). In addition, two significant buildings of the former monastery were still standing: the original seventeenth-century refectory, better known as The Gothic Hall (Sala gotică) due to its interior Gothic vaults, ${ }^{27}$ and the bell tower, reconstructed in 1806, with a Baroque part added in $1830^{28}$ (Figure 8). Therefore, all the actors involved were forced to consider what to do with a significant number of prominent buildings, that were nevertheless seen as interfering with the main monument. Initially, the Ministry intended to transform the Gothic Hall into a 'museum of religious art of Moldova' and Lecomte du Noüy expanded on these plans and proposed to decorate the walls of the future museum with scenes describing the arrival of Saint Parascheva's remains in Iași, together with episodes from the rule of Vasile Lupu, the founder of the monastery. ${ }^{29}$

\footnotetext{
24 “Contract", April 1, 1882, Restaurarea, 125-126.

25 "Report", Lecomte du Noüy fonds, No. 1657, no year. Manuscript Collections, Romanian Academy Library. Lecomte du Noüy composed a list of damages to the church in AD I 309, leaf 26, Engravings Cabinet, Romanian Academy Library.

26 "Letter of A. Lecomte", February 13, 1885, Restaurarea, 168-169, 168. See also "Report", February 8, 1884, Restaurarea, 141.

${ }^{27}$ The Gothic Hall is similar and maybe inspired by the one at Dragomirna monastery, built a few decades earlier in the nearby Suceava county. Dan Bădărău and Ioan Caproșu, Iașii vechilor zidiri: pînă la 1821 (Iași: Casa Editorială Demiurg, 2007), 182.

${ }^{28}$ Sorin Iftimi, "Vechi Turnuri ale Iaşilor", Monumentul (2002), 179-193.

29 "Report", January 12, 1887, Restaurarea 188-193, 188.
} 

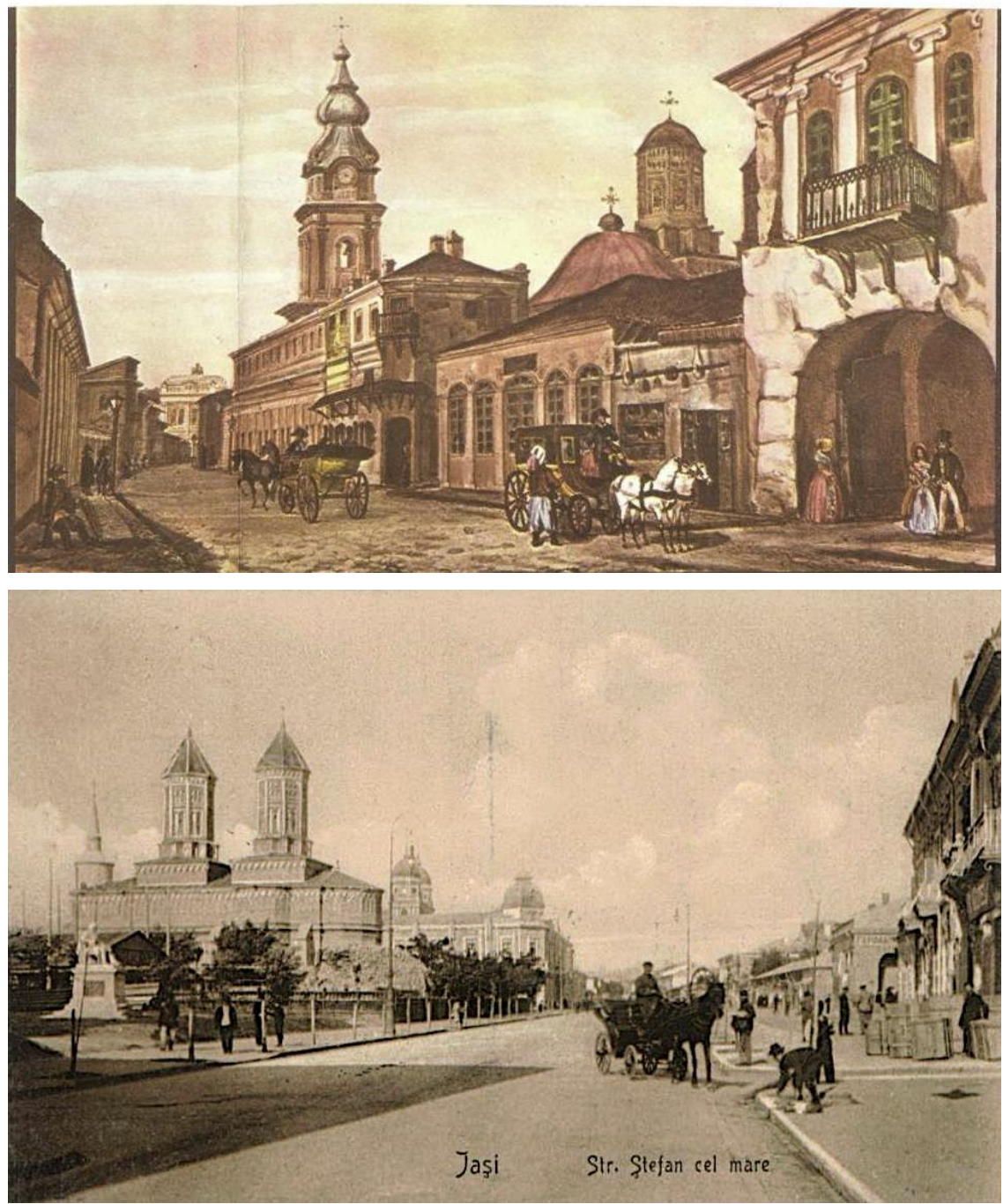

Figure 7: The main thoroughfare in Iași, with Trei Ierarhi Bell Tower and Monastery in the background/ the same road in early twentieth century, after the restoration.

A final decision was not taken until 1890, when another French architect, Henri Revoil (1822-1900), invited to Romania to analyse the restorations, decided that both buildings should be demolished on the grounds that they are not fit for present purposes. He argued that the tower 'does not have any historical or artistic significance' and the Gothic Hall 'does not have the appropriate proportions for the future destination as a history museum'. Consequently, both should be reconstructed 'according to 
its former style but in bigger dimensions and in relation to the new tower'. ${ }^{30}$ The commission also advised that the new tower to be adjacent to the new Gothic Hall and be 'executed in the style of the church and of appropriate dimensions'. ${ }^{31}$ A further reason for demolishing the tower was that it obscured the view of the church from the main thoroughfare of Iasi, Ștefan cel Mare avenue, that was becoming a site for the display of national monuments. Indeed, the whole restoration, including the new museum, can also be seen as part of the rapid urban modernisation of Iași, that included the building of many significant public buildings and monuments at the end of the century. ${ }^{32}$

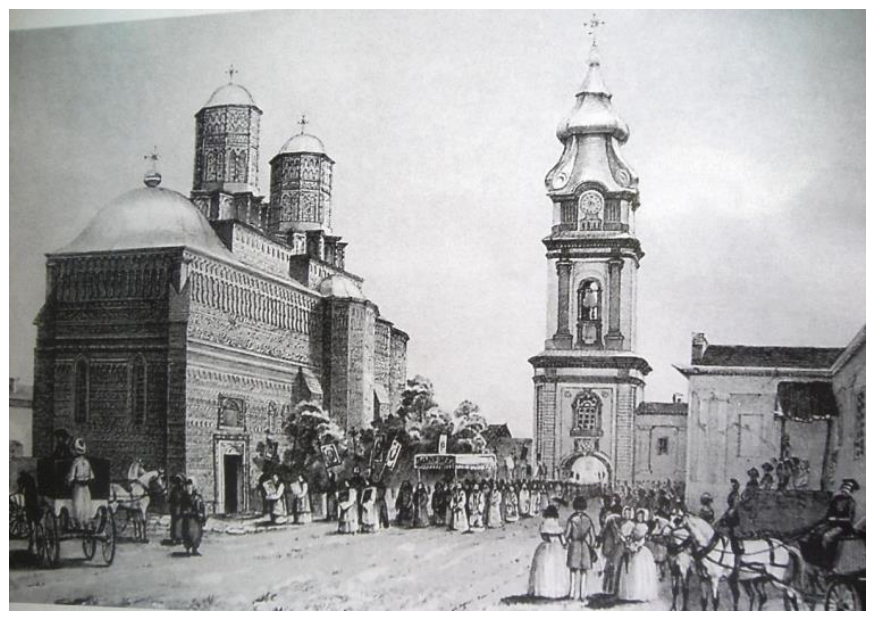

Figure 8: Trei Ierarhi around 1845 (engraving) with a view of the entrance tower and the Gothic Hall at the right.

30 "Report of the commission together with Revoil and Lecomte", June 20, 1890, Restaurarea, 244. See also Grigore Ionescu, "André Lecomte du Nouy et la restauration des monuments historiques de Roumanie",Revista muzeelor şi monumentelor - Monumente istorice și de artă, Anul XLVIII, nr. 1, (1979), 107-113. Grigore Ionescu, "Începuturile lucrărilor de restaurare a monumentelor istorice în România şi activitatea în acest domeniu a arhitectului francez André Lecomte du Nouy”, Revista muzeelor și monumentelor - Monumente istorice şi de artă, Anul XLVII, nr. 1, 1978, 69.

31 "Report of the commission together with Revoil and Lecomte", June 20, 1890, Restaurarea, 244.

${ }^{32}$ In 1882, the most significant public sculpture in the city was finished, the equestrian statue of Stephen the Great (made by the French sculptor Emmanuel Frémiet). See Sorin Iftimi, Cercetari privitoare la istoria bisericilor iesene, (Iași: Doxologia, 2014), 24. Other modern buildings included the University Palace (Louis Blanc, 1896), National Theater (Fellner and Helmer, 1894). A history of the main buildings in Iași in Sorin Iftimi and Aurica Ichim, Strada Ştefan cel Mare Iași Memoria monumentelor, (Iași: Editura Palatul Culturii, 2016). 

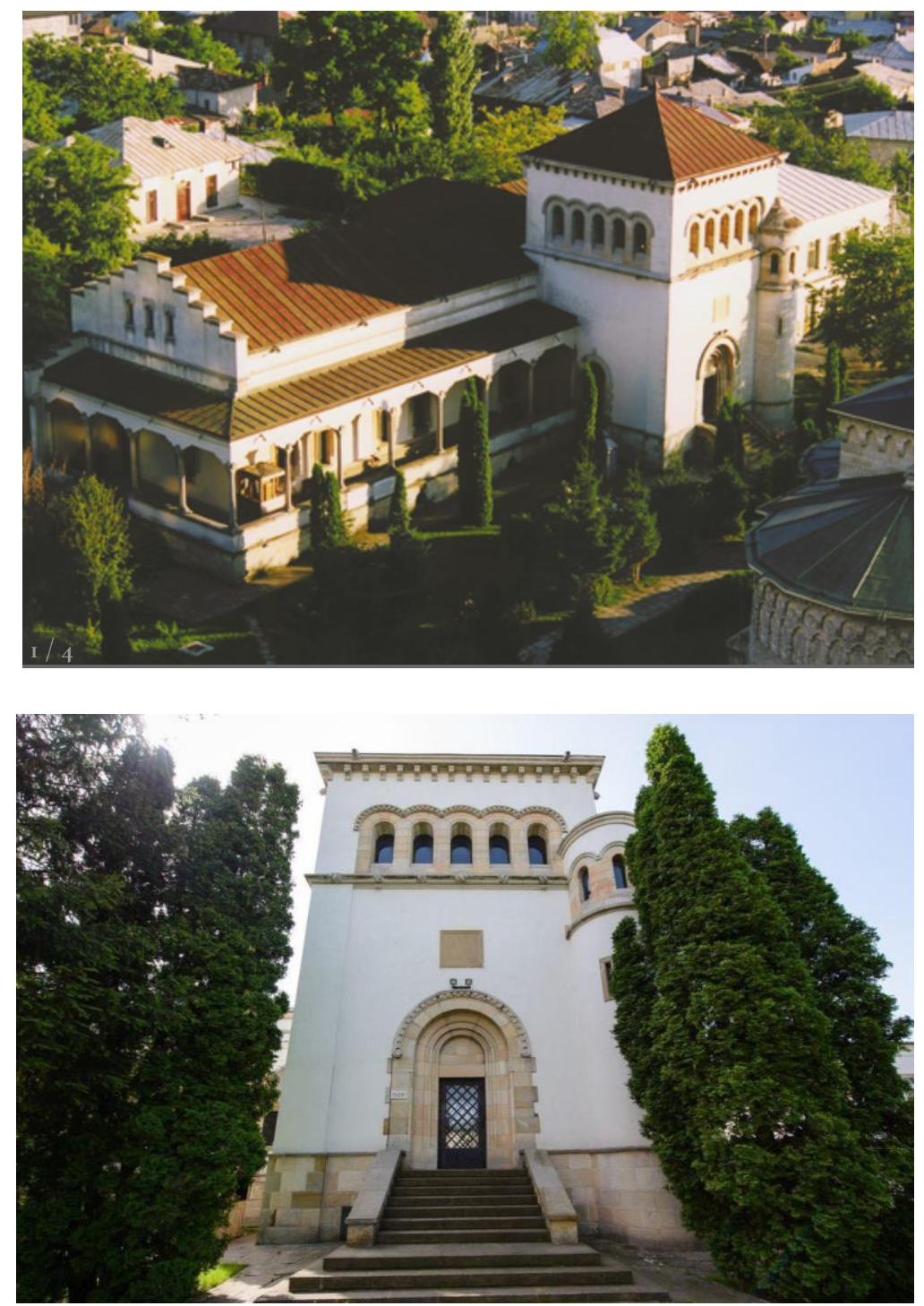

Figure 9: André Lecomte du Noüy, The new Gothic Hall and bell-tower, Trei Ierarhi, finished around 1891.

Following the advice of Henri Revoil, Lecomte du Noüy designed in 1890 a brand new building to serve as a museum, that included a new bell tower as well. However, contrary to Curtea de Argeș, this time he referenced predominantly architecture from Western and Central Europe, probably because he considered it as being more appropriate for a museum (Figure 9). 
The final building is a hall-shaped structure, with gables reminiscent of Central European medieval houses, with an exterior gallery similar to Italian cloisters (such as the cloister of San Giorgio Maggiore in Venice) and with a massive square tower in the middle, looking like a defence structure, somewhat similar to the fortified mansions in Oltenia (South-West Wallachia), known as cule (from the Turkish kule=tower). The main interior room has the same Gothic arcades as the old building, but with enlarged dimensions (Figure 10 and 11).

However, the building works were not finalised at the time, and after a period of neglect the construction was eventually completed in 1960 and the museum opened afterwards to the public. Had it opened as initially planned, it would have been the first public museum in Iași, before the Museum of Antiquities founded only in $1916 .^{33}$
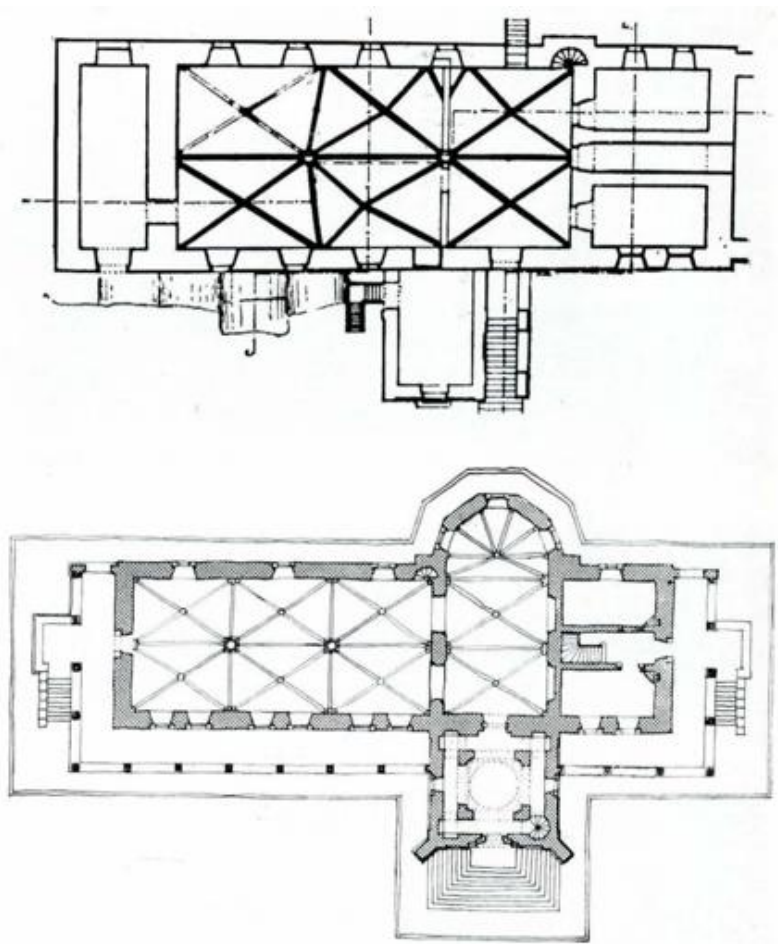

Fig. 1. La salle gothique du monastère des Trois-Hiérarques de Jassy: en haut, le plan ancien (relevé avant restauration); en bas, le plan nouveau (relevé apris restauration). Dessins des archives de Lecomte du Nouy.

Figure 10: Comparison between the plan of the former Gothic Hall and of the new one built by André Lecomte du Noüy.

\footnotetext{
${ }^{33}$ Vasilica Asandei, "Muzeul de Antichităţi din Iaşi: de la primele iniţiative la înfiinţare (18971916)", Historia Universitatis Iassiensis, II/2011, 215-233.
} 

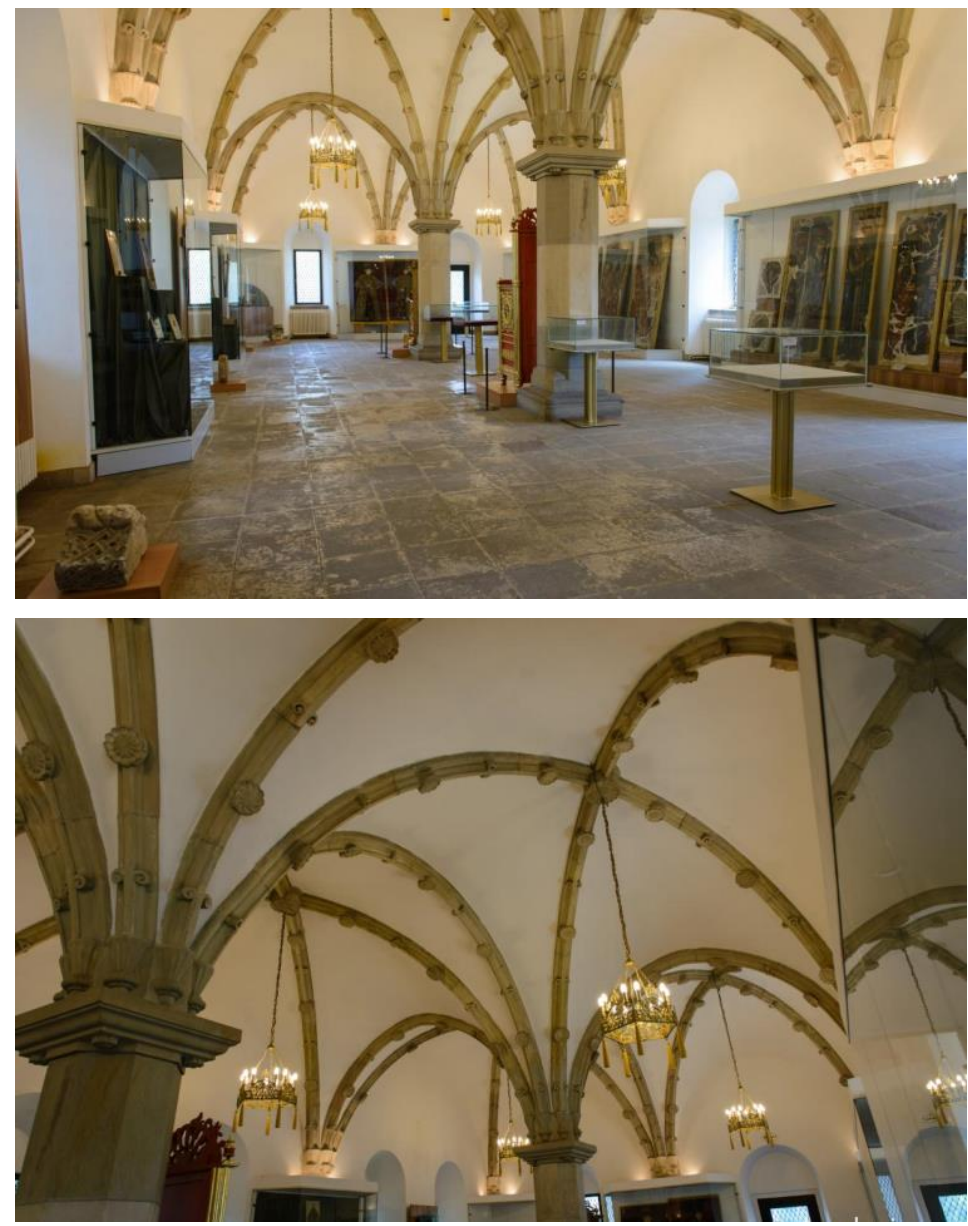

Figure 11: Contemporary views of the Gothic Hall, Trei Ierarhi, Iași.

The creation of museums within or near former monastery buildings can further be seen as a compromise with the influential Romanian Orthodox Church, which argued strongly for its right to conserve and display the historical artefacts found in historical monasteries. Illustrative for the tight relation between the church and the artistic heritage are the debates in the Romanian Parliament for the establishment of an official institution responsible to gather and conserve artefacts and historical monuments, the future Commission for Historical Monuments. This institution was seen by the church as a threat for its right to self-govern and administer ecclesiastical buildings in Romania as it feared to lose a part of its jurisdiction in the case of those classified as historical monuments. The Metropolitan of Moldavia, 
Iosif Naniescu (1818-1902), argued that the church is the best place to conserve historical artefacts; the priests had been compiling inventories of objects for a long time and thus there was no need for a special commission. He also argued that restorations undertaken so far by Lecomte du Noüy had been demolitions rather than real restorations and the local church was actually much knowledgeable to repair and conserve monuments. ${ }^{34}$ The Metropolitan directly criticised Grigore Tocilescu, the director of the Museum of Antiquities, by saying that 'the archaeologist wants to take everything from the church' and compared the situation with someone having their personal belongings abusively taken away. ${ }^{35} \mathrm{He}$ finally argued that a law and a Commission for Historical Monuments were not needed, since the priests are much better at documenting and preserving monuments and artefacts.

Grigore Tocilescu responded with a long, vehement speech listing the many artefacts, manuscripts, and inscriptions that have been damaged or sold outside the country by priests. He argued that 'the canons of aesthetics and architecture are in this case over and above the canons of the church'. ${ }^{36}$ He received applause from fellow senators when he praised principles of secularism: 'The church will not stand in the way of free thinking at the end of our century. ${ }^{37} \mathrm{He}$ argued that a museum was the proper place to exhibit the historical artefacts, and not the original site of a church or monastery. Consequently, the sort of museum proposed by Lecomte du Noüy and by Ion Mincu (detailed in the following section), within the building complex of a church or monastery, seems to be an intelligent middle ground that could have potentially satisfied both the promoters of museums and the church representatives, who did not want to give up their religious artefacts.

\section{The museum for the Romanian architectural heritage designed by Ion Mincu at Stavropoleos Monastery}

For anyone who is a little familiar with modern Romanian art, Ion Mincu (1852-1912) is likely to be a known figure. He is perhaps best described as the Romanian equivalent of the well-known Art Nouveau architects Antoni Gaudí or Eliel Saarinen due to his innovative designs, partly inspired by Romanian architecture. ${ }^{38}$ His attempts at overcoming the

\footnotetext{
34،"Legea pentru conservarea si restaurarea monmentelor istorice", Analele arhitecturei, no. 4, (1892), 63-77, 65.

${ }^{35}$ Ibid., 65 and 66 .

${ }^{36}$ Ibid., 68-69.

${ }^{37}$ Ibid., 68-69.

${ }^{38}$ For a direct comparison between Romania (i.e. Ion Mincu), Catalonia, Finland and Hungary see Jean-Yves Andrieux, Fabienne Chevallier, Anja Kervanto Nevanlinna, Idée nationale et architecture en Europe, 1860-1919. Finlande, Hongrie, Roumanie, Catalogne, (Rennes: Presse Universitaires de Rennes, 2006). See also Carmen Popescu, Le style national roumain:
} 
fashionable European classic or eclectic styles led him to search for new, original architecture and to use previously ignored historical monuments in Romania as source of inspiration. The small Stavropoleos church in Bucharest (built in 1724) is a good case in point. Ignored or even openly criticised by intellectuals of the time (because of its size, recent date of construction or lack of historical significance $)^{39}$, it was appreciated by Mincu, as from his point of view the original decorations and architecture of the monument reflected the local artistic production. Indeed, his restoration modified the monument in order to single out its original characteristics, an opposite aim from that of André Lecomte du Noüy, whose restorations gave monuments a uniform neo-Byzantine style. ${ }^{40}$

After several inconclusive restoration attempts, the Ministry of Religious Cults and Public Instruction asked Mincu in 1897 to study the restoration of the church. Mincu was strongly discouraged by the way the church was constructed, with no foundations, cheap materials and weakened walls. ${ }^{41} \mathrm{He}$ found that preservation would encounter 'serious difficulties' and 'seems impossible'. ${ }^{42}$ At the same time, he criticised the 'hidden and small plot' on which the church was placed, with 'abhorrent surroundings', namely massive and tall modern buildings. ${ }^{43}$ Consequently, he made the radical proposition that the church be completely demolished, and reconstructed in another place, where 'to reuse all the old stone that are well preserved, and to remake faithfully the forms and dimensions of the current building' ${ }^{44}$ Mincu further proposed that the church be in the centre of a new museum for the

construire une nation à travers l'architecture, 1881-1945 (Rennes: Presses universitaires de Rennes, 2004); Ada Hajdu, "The Search for National Architectural Styles in Serbia, Romania, and Bulgaria from the Mid-Nineteenth Century to World War I," in Entangled Histories of the Balkans. Volume Four: Concepts, Approaches, and (Self-)Representations, ed. Roumen Daskalov et al., vol. 4 (Leiden: Brill, 2017), 394-439.

${ }^{39}$ See Alexandru Țigara-Samurcaş, "Stavropoleos - Muzeu Național", Epoca, November 17, (1903), in Scrieri Despre Arta Romanească (Bucharest: Meridiane, 1987), 258-63; Alexandru Țigara-Samurcaș, "Stavropoleos - Muzeu Național", Epoca, February 26, (1904)", in Scrieri Despre Arta Romanească (Bucharest: Meridiane, 1987), 264-69.

${ }^{40}$ See also Cosmin Minea, "Restoration of Historical Monuments in Twentieth-Century Europe: 'The Battle For Stavropoleos"', Blog Post, Art Historiographies in Central and Eastern Europe. An Inquiry from the Perspective of Entangled Histories. URL:

https://arthist.ro/2020/10/restoration-of-historical-monuments-in-twentieth-century-europethe-battle-for-stavropoleos/

${ }^{41}$ Report of January 5, 1900 in the Archive of the Ministry of Religion as reproduced in Nedioglu, "Stavropoleos", 163. Nedioglu, 163.

${ }^{42}$ Gheorghe Nedioglu, "Stavropoleos",Buletinul Comisiunii Monumentelor Istorice, no. 42 (October 1924), 163. Also, Petrascu said that Mincu was unhappy with the foundation structure and with the suroundings of the church: Petrascu, "Ioan Mincu", 90.

${ }^{43}$ Gheorghe Nedioglu, "Stavropoleos",Buletinul Comisiunii Monumentelor Istorice, no. 42 (October 1924, 163.

${ }^{44}$ Ibid., 163. 
Romanian architectural heritage, therefore changing its function as monastery. He envisaged:

the reconstructed monument to be surrounded on three sides with galleries and open porches in the same architectural style, in order to on the one hand constitute an interesting and noble view, and on the other to be an open museum, in which many fragments of local architecture to be displayed. $^{45}$
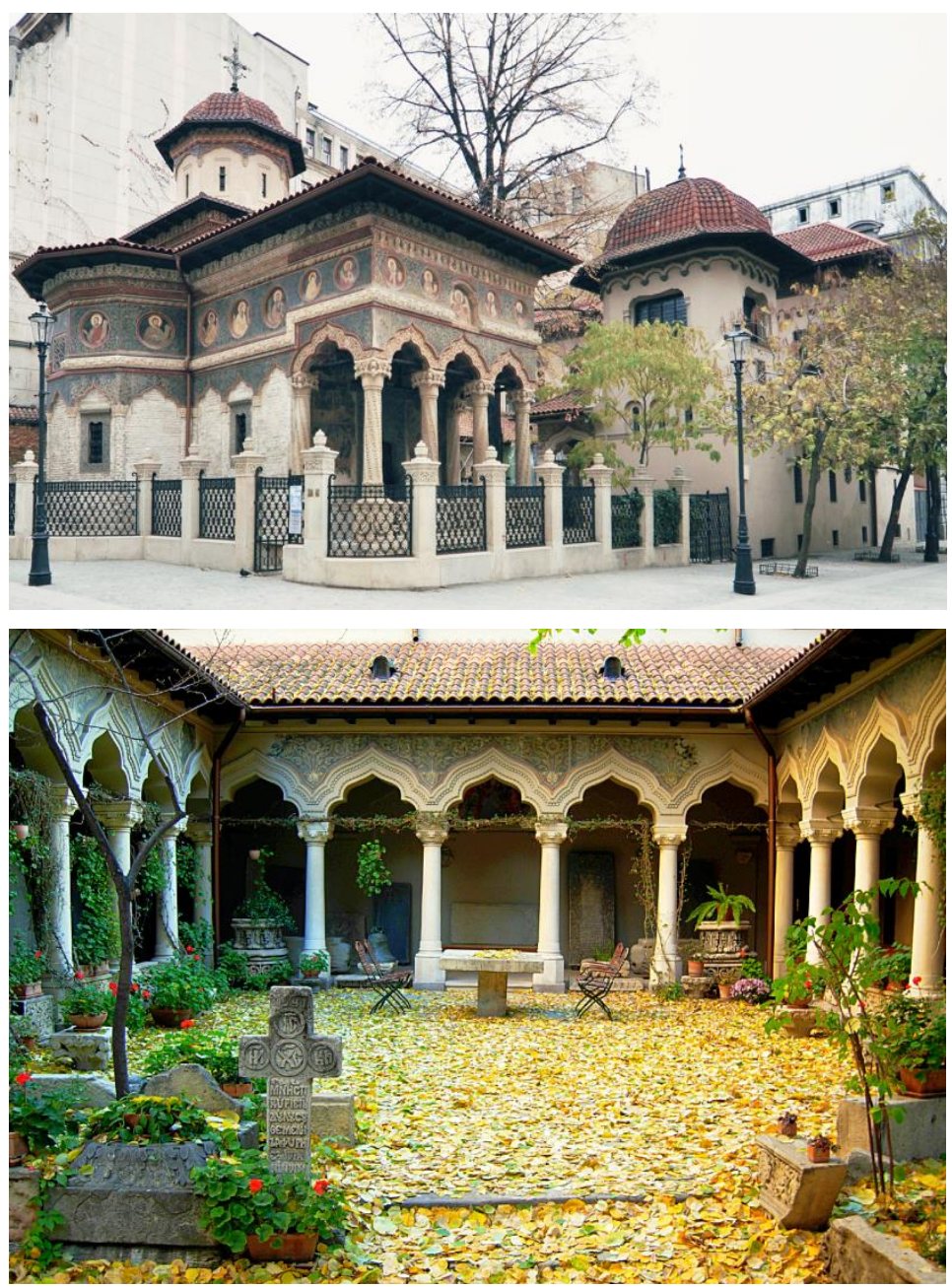

Figure 12: Stavropoleos monastery after the restoration by Ion Mincu (1904-1907) / courtyard of the monastery (1908-1910).

${ }^{45}$ Ibid., 163. 
Mincu's restoration proposal is remarkable as it envisaged transformations more radical than other architects before him. For example, the French architect Henri Revoil, who visited Romania a few years before to defend André Lecomte du Noüy, only suggested the remaking of decorations, the tower and structural elements, without demolishing the monument and relocating it. ${ }^{46}$ Therefore, Mincu appeared to be even more keen to transform the monument than the foreigners criticised by other Romanian architects. Nevertheless, his image as founder of the Neoromanian architectural style made the episode about Stavropoleos restoration to be conveniently ignored by scholars, the more so as his career was often pitted against that of foreign architects, active in Romania at the time.

The rejection of Mincu's restoration led eventually to a long postponement. After four years, the Commission for Historical Monuments asked Mincu again to propose a restoration plan and the architect offered further arguments for a demolition and relocation of the monument. $\mathrm{He}$ recognised that the new building would be just a copy of the original monument but planned to integrate in it some of the original decorations, "so that the coldness of the copy, no matter how perfect, to be alleviated by the presence of many original elements' ${ }^{47}$ He then argued that a copy will be more useful for the artistic study of the heritage, instead of an original, but damaged monument:

The consolidation would not prevent the disappearance with time of many artistic elements. A perfect copy of the church should be built in another place, in order for the next generations of artists to have preserved a detailed example of the last phase of development reached by our domestic art. ${ }^{48}$

Mincu reached in the end a compromise with the Commission for Historical Monuments on the restoration of Stavropoleos. He did not demolish or moved the monument, but restored it and built a museum surrounding it, as he initially proposed. The work lasted four years and included the replacement and repainting of the exterior decoration, together with the replacement of twenty-four capitals, and replacement of the middle freeze, barely visible at the time, with a new, stone one; rebuilding of a new tower, as seen in the votive painting; replacement of the roof; restoration of the inside furnishing ${ }^{49}$ (Figure 12). Mincu was indeed not interested in historical accuracy, but in the aesthetic quality of the heritage ${ }^{50}$ For Mincu, the heritage was not something sacred, that deserved to be frozen in time, as

\footnotetext{
${ }^{46}$ Henri Revoil, "Raport despre biserica Stavropoleos", 279-280.

${ }^{47}$ Meetig of June 12, 1904 in Nedioglu, "Stavropoleos", 164.

${ }^{48}$ March 12, 1904 in Ibid., 164.

${ }^{49}$ Mincu's restoration report from June 16, 1904 in Nedioglu, "Stavropoleos", 165.

${ }^{50}$ This was also the criticism by one of his last students. See Toma T. Socolescu, Fresca arhitecţilor care au lucrat în România în epoca modernă: 1800-1925, (Bucharest: Caligraf Design, 2004), 108.
} 
some of his colleagues argued, but something to be reshaped, modified and made usable in the contemporary society. He preferred to embellish the monument and to recreate in this way a Romanian heritage that could serve as inspiration source for contemporary architects. The restoration, while similar in principles to that of André Lecomte du Noüy, also reveals his modern outlook.
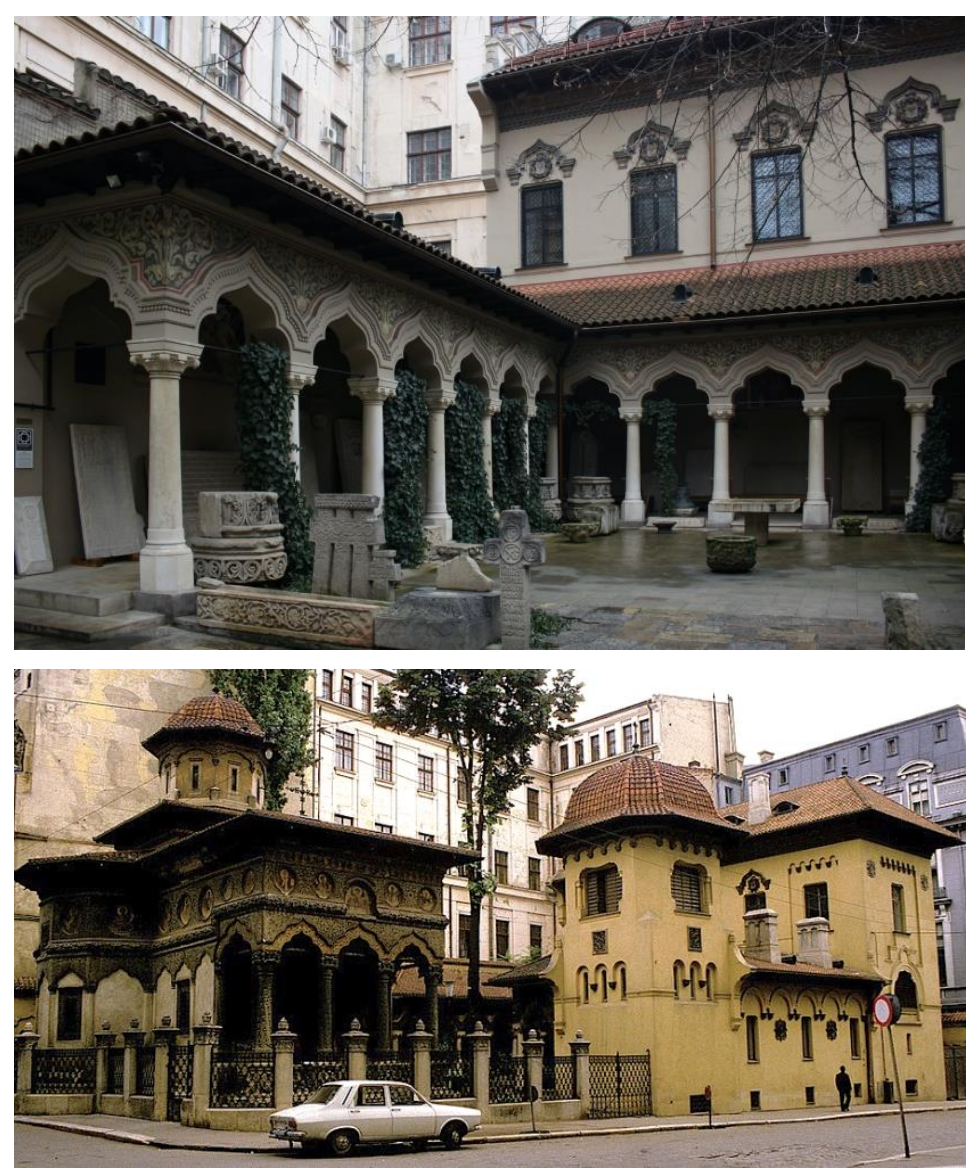

Figure 13: Ion Mincu, Stavropoleos monastery: inner courtyard and the new buildings.

For the future museum, designed in 1908, Mincu imagined a unique eclectic construction that referenced architectural and decorative elements from the church, but on a monumental scale, in a two-storey high building that also included a bell tower. (Figure 13) The cloister (the monastery was re-established in 1991), formed by rows of trefoil arcades that copy the ones 
from the porch, also resembles Catholic monasteries from Italy or Spain. ${ }^{51}$ The designs are relevant for the multiplication of artistic sources and the experiments with various architectural motifs that marked the later part of Mincu's career. Elements from Romanian heritage were combined with great freedom and mixed with some other sources. He put into practice his teachings as professor, namely the unrestrained creative experiments with the past heritage that gave birth to various architectural forms. Indeed, the heterogenous and original nature of his later designs contradict once again the idea of a uniform Romanian national style.

Today, the re-established monastery partially keeps its initial role of a museum. ${ }^{52}$ It has a library and a rich collection of ecclesiastical objects, such as icons, tapestries, wood sculptures or cultic objects kept in one of the main rooms of the building, that can be seen during private tours organised by the custodian of the museum, Sister Anastasia. ${ }^{53}$ (Figure 14).

While Mincu's proposal for a museum of religious art was debated, a new museum of art opened in Bucharest in 1906, The Museum of Ethnography, National Art, Decorative Art and Industrial Art (Muzeul de Etnografie, de Artă Naţională, Artă Decorativă şi Artă Industrială). It was focused on folk art and established by Alexandru T,igara-Samurcaș (18721952), the first ever Romanian with a doctorate in art history (University of Munich, in 1896). Samurcaș was a promoter of folk art as a significant part for the cultural identity of Romania and, not surprisingly, was against the restoration or reconstruction of Stavropoleos monastery, that he considered as lacking historical value and naming it 'a country-church'. ${ }^{54}$ However, Samurcaș did not succeed in taking the attention away from the religious art of Romania. On the contrary, with the rise of the Neoromanian architectural style and the building of numerous and imposing Orthodox cathedrals and churches throughout the country, but mostly in Transylvania after it became part of Romania in 1918, the religious heritage played an essential role for the Romanian art and culture.

\footnotetext{
${ }^{51}$ Irina Baldescu even suggested that monastic cloisters from Spain and Itlay were a direct source of inspiration. See Irina Băldescu, "Restaurarea Din Pragul Secolului XX. Materie și Imagine între Conservare și Retuşuri. Restaurarea de La Stavropoleos şi Contextul Cultural",Stavropoleos Monastery Archive, (2002), 17.

${ }^{52} \mathrm{https} / / /$ www.stavropoleos.ro/manastirea/colectia/

${ }^{53}$ I thank Sister Anastasia for providing me with information about the history of Stavropoleos Monastery as well as for the tours of the museum.

54 Alexandru Țigara-Samurcaş, "Stavropoleos - Muzeu Naţional", Epoca, February 26, (1904)", in Scrieri Despre Arta Romanească (Bucharest: Meridiane, 1987), 264-69, especially 260-61.
} 

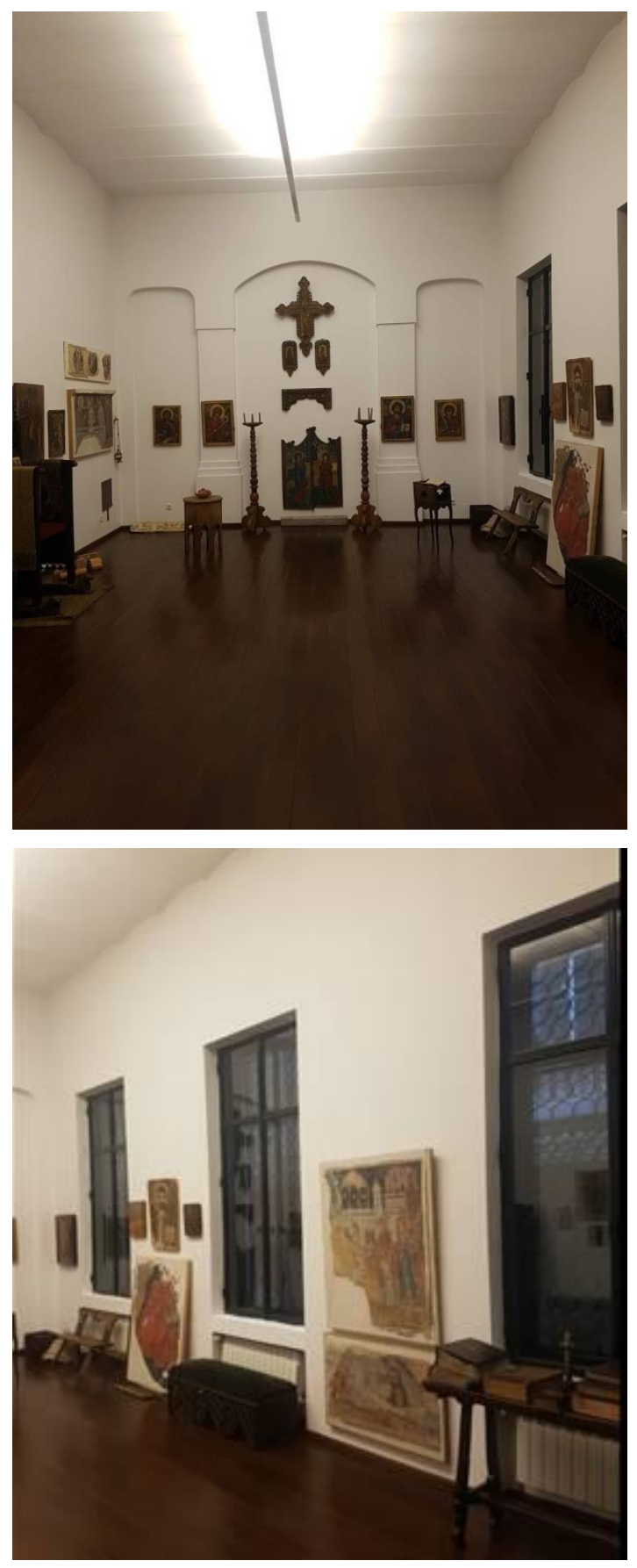

Figure 14: Interior views of Stavropoleos Museum. 


\section{Conclusions}

This article analysed the first initiatives to build museums of medieval and religious art in Romania and placed them in the wider context of the drive to create and display a national heritage in the country. In the 19th century, this activity was fundamentally linked to the material patrimony of the Romanian Orthodox church and with the way churches and monasteries were restored and given new symbolic meanings. While usually presented as part of a glorious history of the early Romanian state, a time when fundamental institutions were established, literary and scientific works were written, and cities were modernised, the emergence of museums incurred destruction as much as construction, as this article has shown. Museums were created through the modification of the urban and architectural landscape, being symptoms of the new, modern determination to shape history and to offer a clear narrative that would justify the present political status.

Museums and collections of religious art emerged gradually, as Romania itself discovered its medieval heritage. As shown, the 19th century was a time when the attention was mostly directed towards findings from the Roman period, more significant for the ethnic identity of Romanians. However, the substantial visible proof of the country's past were medieval monuments that comprised almost exclusively churches and monasteries. They could not be ignored and in fact, ever since the creation of the modern state, there have been attempts at documenting and restoring the monuments and gather artefacts from inside these buildings. However, a systematic study of monuments was equally not published until the early twentieth century, when the Bulletin of the Commission for Historical Monuments (Buletinul Comisiunii Monumentelor Istorice) was first issued in 1908, and further, in 1914, with the Almanac of the Commission for Historical Monuments (Anuarul Comisiunii Monumentelor Istorice). Indeed, a history of old Romanian art, based on these studies, was first published outside Romania, in Paris, and only in $1922 .^{55}$

The activity of restoring religious monuments and constituting collections of medieval art was viewed differently by various actors. Politicians, for example, insisted that the collections should be taken to the Museum of Antiquities in Bucharest and the monuments themselves be modified so that to become suitable for a modern state. The religious figures opposed these actions and argued for the need to have artefacts kept inside churches. Finally, architects proposed new buildings within monasteries or churches, that could serve as museums of religious art.

\footnotetext{
${ }^{55}$ Nicolae Iorga and Gheorghe Balș, Histoire de l'art roumain ancient, (Paris, 1922).
} 
The restoration of monuments and the emergence of museums went hand in hand with the emergence of art museums and can be seen as having a similar effect for the concept of national heritage. Urban surroundings were modified so that the monuments fit in a new, modern urban fabric and in a similar way objects were taken from their historical context and exhibited in museums. Historical monuments were recognised after their restorations as national symbols and the objects were given an increased 'national' importance after their display in museums.

The restorations, as well as the activity of establishing new museums, were essentially a project of an international artistic elite (local authorities, local and foreign artists), whose mission was to transform and promote the artistic heritage in Romania. The phenomenon of the local elites internalising the Western gaze over Balkans or Eastern Europe has been called selfcolonisation' or 'nesting orientalism'. ${ }^{56}$ The process indeed parallels a civilizing mission, in which the colonists were not only foreigners, but also foreign-educated Romanian elites and the political context was not imperial, but national. Hidden by the shiny new buildings and the prestigious museum collections, serious social discrepancies and a huge gap in the life standard between the elite and the majority of the population existed. This was directly reflected in the process of promoting a national heritage, that remained a concern of a small elite, mostly based in Bucharest, and directed towards shaping an official, prestigious image of Romania, inside and outside the country. At the same time, the needs or voices of local communities were largely ignored. Ultimately, the restored monuments and the museums were (and still are) not only an integral part of the nation-building efforts, but also an instrument for a highly controlled and politicised artistic display.

\section{Figures and Credits:}

Figure 1: Henri Trenk, View of Curtea de Argeș, Watercolour, 1860. Credits: National Museum of Arts, Bucharest

Figure 2: Bisson Freres Studio, view of the Romanian section, 1867 Paris Universal Exhibition. Credits: Musee D'orsay, Documentation de la conservation. Architecture. Box 48 - Ambroise Baudry.

Figure 3: Curtea de Argeș before the restoration after the exterior restoration (around 1881). Credits: Archives of the University of Architecture, Bucharest

Figure 4: Trei Ierarhi Church, Iași, seventeenth century, restored between 1884-1887 Credits: Bogdan29roman

Figure 5: Cathedral of Saint Demetrius, Vladimir, Russia (late twelve century) displaying the same rich stone-carved decoration on the exterior façade as Curtea de

\footnotetext{
${ }^{56}$ Alexander Kiossev, "The Self-Colonising Cultures", in Cultural Aspects of the Modernization Process, ed. Dimitri Ginev and Francis Sejersted, (Oslo: TMV, 1996).Milica Bakić-Hayden, "Nesting Orientalisms: The Case of Former Yugoslavia", Slavic Review 54, no. 4 (1995), 917-931.
} 
Argeș and Trei Ierarhi churches and which Viollet-le-Duc compared with previous Armenian and Georgian monuments

Credits: www.pixabay.com

Figure 6: Comparison between the roof and towers before and after the restoration. Credits: National University of Architecture Archive / Bogdan29roman

Figure 7: The main thoroughfare in Iași, with Trei Ierarhi Bell Tower and Monastery in the background/ the same road in early twentieth century, after the restoration.

Credits: J. Rey, Album de douze Vues de la ville de Jassi, executées par J. Rey et dediée À son Altesse le Prince Régnant de la Moldavie par P. Müller, lithographe, (1845) / http://www.ziarulevenimentul.ro/data/_editor/1stefan_vechi.jpg

Figure 8: Trei Ierarhi around 1845 (engraving) with a view of the entrance tower and the Gothic Hall at the right. Credits: J. Rey, Album de douze Vues de la ville de Jassi, executées par J. Rey et dediée À son Altesse le Prince Régnant de la Moldavie par P. Müller, lithographe, 1845

Figure 9: André Lecomte du Noüy, The new Gothic Hall and bell-tower, Trei Ierarhi, finished around 1891.Credits: www.manastireasftreiierarhi.ro

Figure 10: Comparison between the plan of the former Gothic Hall and of the new one built by André Lecomte du Noüy. Credits: Grigore Ionescu, "André Lecomte du Nouy et la restauration des monuments historiques de Roumanie", Revista muzeelor şi monumentelor - Monumente istorice și de artă, Anul XLVIII, nr. 1, (1979), 107$113,110$.

Figure 11: Contemporary views of the Gothic Hall, Trei Ierarhi, Iași. Credits: Ana Nechifor, doxologia.ro

Figure 12: Stavropoleos monastery after the restoration by Ion Mincu (1904-1907) / courtyard of the monastery (1908-1910). Credits: Luca Volpi (Goldmund100)

Figure 13: Ion Mincu, Stavropoleos monastery: inner courtyard and the new buildings. Credits: https://marcin-roguski.info

Figure 14: Interior views of Stavropoleos Museum. Credits: The Author, Cosmin Minea.

\section{Bibliography:}

"Legea pentru conservarea si restaurarea monmentelor istorice", Analele arhitecturei, no. 4, (1892), 63-77.

Andrieux, Jean-Yves, Chevallier, Fabienne, Kervanto Nevanlinna, Anja, Idée nationale et architecture en Europe, 1860-1919. Finlande, Hongrie, Roumanie, Catalogne, (Rennes: Presse Universitaires de Rennes, 2006).

Asandei, Vasilica, "Muzeul de Antichităţi din Iaşi: de la primele iniţiative la înfiinţare (1897-1916)”, Historia Universitatis Iassiensis, II/2011, 215-233.

Asandei, Vasilica, Arheologie Și Muzeologie în România la Sfârşitul Secolului Al Xix-Lea Și Inceputul Secolului Al Xx-Lea (Metode Şi Concepții), PhD Thesis, Universitatea „Alexandru Ioan Cuza” Din Iaşi Facultatea De Istorie, (2020).

Bakić-Hayden, Milica, "Nesting Orientalisms: The Case of Former Yugoslavia", Slavic Review 54, no. 4 (1995), 917-931. 
Bădărău, Dan, Caproșu, Ioan, Iașii Vechilor Zidiri: Pînă La 1821 (Iași: Demiurg, 2007).

Băldescu, Irina, "Restaurarea Din Pragul Secolului XX. Materie și Imagine între Conervare și Retuşuri. Restaurarea de La Stavropoleos şi Contextul Cultural”, Stavropoleos Monastery Archive, (2002).

Balș, Gheorghe, Influences arméniennes et géorgiennes sur l'architecture roumaine, (Vălenii de Munte, 1931);

Bolliac, Cesar, Monastirile din Romania. (Monastirile inchinate), (Bucharest, 1862).

Brouwer, Petra \& Jõekalda, Kristina, "Introduction: architectural identities of European peripheries", (2020), The Journal of Architecture, 25:8, 963-977.

Cernea, Emanuela, Boldura, Oliviu, et all., Mărturii. Frescele Mănăstirii Argeşului, Exhibition catalogue, (MNAR: Bucharest, 2013).

Deen Schildgen, Brenda, Heritage or Heresy: Preservation and Destruction of Religious Art and Architecture in Europe (New York: Palgrave Macmillan, 2016).

Dobjanschi, Ana, Simion, Victor, "Un climat nou de arta in epoca lui Vasile Lupu", Revista Muzeelor si Monumentelor, XV, (1984).

Ducuing, François, “L'Eglise roumaine”, in L'Exposition illustrée, tom I, (1867).

Fonds Ministry of Religion and Public Instructions, National Archives of Romania, Bucharest, dossier no. 127, year 1874

Ghika-Budești, Nicolae, "Înrâurirea armenească”, Buletinul Comisiunii Monumentelor Istorice, Part. 1, (1927), 140-146.

Ghika, Pantazi, Monumente Naționali. Monastiri şi biserici ortodocse. Raporturi de la comisiunile întocmite pentru cercetarea lor, Vol 1, (Bucharest, 1882).

Glendinning, Miles, The Conservation Movement: A History of Architectural Preservation: Antiquity to Modernity (New York: Routledge, 2013).

Hajdu, Ada, "În Căutarea Patrimoniului. Excursiile Patriotice Şi Arhitectura Naţională Românească În Secolul al XIX-Lea," in Călători Și Călătorii. A Privi, a Descoperi, ed. Bogdan, Cristina and Silvia Marin Barutcieff, vol. 1 (Bucharest: Editura Universității din București, 2016), 149-68.

Hajdu, Ada, "The Search for National Architectural Styles in Serbia, Romania, and Bulgaria from the Mid-Nineteenth Century to World War I," in Entangled Histories of the Balkans. Volume Four: Concepts, Approaches, and (Self-)Representations, ed. Roumen Daskalov et al., vol. 4 (Leiden: Brill, 2017), 394-439.

Idieru, Nicolae, Istoria Artelor Frumoase, (Bucharest, 1898).

Iftimi, Sorin, Ichim, Aurica, Strada Ştefan cel Mare Iaşi Memoria monumentelor, (Iași: Editura Palatul Culturii, 2016),

Iftimi, Sorin, "Vechi Turnuri ale Iașilor”, Monumentul (2002), 179-193.

Iftimi, Sorin, Cercetari privitoare la istoria bisericilor iesene, (Iași: Doxologia, 2014).

Ionescu, Grigore, "André Lecomte du Nouy et la restauration des monuments historiques de Roumanie", Revista muzeelor și monumentelor - Monumente istorice şi de artă Anul XLVIII, nr. 1, (1979), 107-113. 
Ionescu, Grigore, "Începuturile lucrărilor de restaurare a monumentelor istorice în România și activitatea în acest domeniu a arhitectului francez André Lecomte du Nouy”, Revista muzeelor şi monumentelor - Monumente istorice şi de artă, Anul XLVII, nr. 1, 1978.

Iorga, Nicolae, Balș, Gheorghe, Histoire de l'art roumain ancient, (Paris, 1922).

Istrate, Alexandru, De la gustul pentru trecut la cercetarea istoriei. Vestigii, călătorii și colecționari în România celei de-a doua jumătăți a secolului XIX, (Iași: Editura Universităţii Al. I. Cuza din Iaşi, 2015);

Jokilehto, Jukka, A History of Architectural Conservation (Oxford: ButterworthHeinemann, 2002).

Kiossev, Alexander, "The Self-Colonising Cultures", in Cultural Aspects of the Modernization Process, ed. Dimitri Ginev and Francis Sejersted, (Oslo: TMV, 1996).

L'Exposition illustrée, tom II, 1900, 130-132.

Manuscript Collections, Romanian Academy Library AD I 309,

Lăzărescu, Emil, Biserica Mânăstirii Argeşului (The Church of the Argeș Monastery), (Bucharest: Meridiane, 1967).

Minea, Cosmin, "The Monastery of Curtea de Argeș and Romanian Architectural Heritage in the Late 19th Century," Studies in History and Theory of Architecture 4 (2016): 191-94.

Minea, Cosmin, "Restoration of Historical Monuments in Twentieth-Century Europe: "The Battle For Stavropoleos", Blog Post, Art Historiographies in Central and Eastern Europe. An Inquiry from the Perspective of Entangled Histories. URL: https://arthist.ro/2020/10/restoration-of-historical-monuments-in-twentieth-centuryeurope-the-battle-for-stavropoleos/

Nedioglu, Gheorghe, "Stavropoleos", Buletinul Comisiunii Monumentelor Istorice, no. 42 (October 1924), 163.

Odobescu, Alexandru, "Chestionarul Odobescu”, 1871-1874, Manuscript 223-230, Library of the Romanian Academy, Manuscript Cabinet.

Odobescu, Alexandru, Biserica de la Curtea de Argeș, (Bucharest, 1924);

Odobescu, Alexandru, Notice sur les antiquites de la Roumanie, (Paris: A. Franck, 1868).

Odobescu, Alexandru, Opere complete, vol. 3, (Bucharest, 1906).

Odobescu, Alexandru, Scrieri Literare si Istorice, (Bucharest, 1887).

Odobescu, Alexandru, Aurelian, Petre, Notice sur la Roumanie: principalement au point de vue de son économie rurale, industrielle et commerciale, (Paris: A. Franck, 1868);

Pelimon, Alexandru, Descrierea Sfintelor Monastiri, de A. Palemon. Memoriu. (Bucharest, 1861). 
Piotrowski, Piotr, "Toward a Horizontal History of the European Avant-Garde," in Europa! Europa? The Avant-Garde, Modernism and the Fate of a Continent, ed. Bru Sascha (De Gruyter, 2009), 49-58.

Popescu, Carmen, “André Lecomte Du Nouÿ (1844-1914) et La Restauration Des Monuments Historiques En Roumanie," Bulletin de La Société de l'Histoire de l'Art Français. Année 1998, 1999, 287-308.

Popescu, Carmen, Le style national roumain: construire une nation à travers l'architecture, 1881-1945 (Rennes: Presses universitaires de Rennes, 2004).

Carmen Popescu, "Cultures majeures, cultures mineures". Quelques réflexions sur la (géo)politisation du folklore dans l'entre-deux-guerres', in Spicilegium. Studii și articole în onoarea Prof. Corina Popa, (Bucharest: UNArte, 2015).

Reissenberger, Ludwig, "Die bischöfliche Klosterkirche bei Kurtea d'Argyisch in der Walachei”, Jahrbuch der Kaiserl. Königl. Central-Commission zur Erforschung und Erhaltung der Baudenkmale, IV (1860).

Restaurarea monumentelor istorice, 1865-1890, Acte şi rapoarte oficiale, (Bucharest, 1890).

Tzigara-Samurcaș, Alexandru, "Stavropoleos - Muzeu Naţional”, Epoca,

November 17, (1903), in Scrieri Despre Arta Romanească (Bucharest: Meridiane, 1987), 258-63.

Tzigara-Samurcaș, Alexandru, "Stavropoleos - Muzeu Naţional”, Epoca, February 26, (1904)", in Scrieri Despre Arta Romanească (Bucharest: Meridiane, 1987), 26469.

Tzigara-Samurcaş, Alexandru, Biserica Episcopală din Curtea de Argeş, (Bucharest, 1913);

Sarcedotianu, Aurelian, Cercetări istorice și pitorești prin mânăstirile noastre acum optzeci de ani, [Picturesque and historical research in our monasteries eighty years ago] (Bucharest, 1941).

Slavici, Ioan, Mandrea, George, Monumente Naţionali. Monastiri şi biserici ortodocse. Raporturi de la comisiunile întocmite pentru cercetarea lor, Vol 2, (Bucharest, 1882).

Socolescu, Toma T., Fresca arhitecţilor care au lucrat în România în epoca modernă: 1800-1925, (Bucharest: Caligraf Design, 2004).

Sullivan, Alice Isabella, "Ecclesiastical Art and Architecture at the Crossroads: The Three Hierarchs Church in Iaşi” in George Lăzăroiu, ed., Thraco-Dacian and Byzantine Romanity of Eastern Europe and Asia Minor, vol. XI, (New York: The Romanian Institute of Orthodox Theology and Spirituality, 2012).

Târnă, Mirela, "Conceptul de Muzeu National • Studiu De Caz: Muzeul NationaL De Antichităti Din Bucuresti”, Bucureşti. Materiale de istorie și muzeografie, Vol. XIX, (2005).

Tocilescu, Grigore, Documente privitoarere la Istoria Romanilor, (Bucharest, 18851886). 
Tocilescu, Grigore, Otto Benndorf and George Niemann, Das monvment von Adamklissi, Tropaevm Traiani, (Vienna, 1895).

Tocilescu, Grigore, Raporturi asupra câtorva mănăstiri, schituri și biserici din țeră, (Bucharest, 1887)

Vlachou, Foteini, "Notes from the Periphery: History and Methods", Visual Resources, Volume 35, Issue 3-4, 2019, 193-199.

Vlad, Laurențiu, Imagini ale identităţii naţionale. România şi expoziţiile universale de la Paris, 1867-1937, (Iași: Institutul European, 2007).

Zach, Kirsta, "Der Furstenhof in Argeș", in Religiöse Erinnerungsorte in Ostmitteleuropa: Konstitution und Konkurrenz, ed. Joachim Bahlcke, Stefan Rohdewald, Thomas Wünsch, (Akademie Verlag, 2013), 99-110. 